\title{
Fluid-rock interactions in the shallow Mariana forearc: carbon cycling and redox conditions
}

\author{
Elmar Albers ${ }^{1}$, Wolfgang Bach ${ }^{1}$, Frieder Klein ${ }^{2}$, Catriona D. Menzies ${ }^{3, a}$, Friedrich Lucassen ${ }^{1}$, and \\ Damon A. H. Teagle ${ }^{3}$ \\ ${ }^{1}$ Department of Geosciences and MARUM - Center for Marine Environmental Sciences, University of Bremen, \\ Bremen, 28359, Germany \\ ${ }^{2}$ Department of Marine Chemistry and Geochemistry, Woods Hole Oceanographic Institution, \\ Woods Hole, MA 02543, USA \\ ${ }^{3}$ School of Ocean and Earth Science, National Oceanography Centre Southampton, University of Southampton, \\ Southampton, SO14 3ZH, UK \\ a now at: Department of Geology and Petroleum Geology, University of Aberdeen, Aberdeen, AB24 3FX, UK
}

Correspondence: Elmar Albers (e.albers@uni-bremen.de)

Received: 12 March 2019 - Discussion started: 22 March 2019

Revised: 19 May 2019 - Accepted: 24 May 2019 - Published: 24 June 2019

\begin{abstract}
Few data exist that provide insight into processes affecting the long-term carbon cycle at shallow forearc depths. To better understand the mobilization of $\mathrm{C}$ in sediments and crust of the subducting slab, we investigated carbonate materials that originate from the subduction channel at the Mariana forearc $(<20 \mathrm{~km})$ and were recovered during International Ocean Discovery Program Expedition 366. Calcium carbonates occur as vein precipitates within metavolcanic and metasedimentary clasts. The clasts represent portions of the subducting lithosphere, including ocean island basalt, that were altered at lower blueschist facies conditions and were subsequently transported to the forearc seafloor by serpentinite mud volcanism. Euhedral aragonite and calcite and the lack of deformation within the veins suggest carbonate formation in a stress-free environment after peak metamorphism affected their hosts. Intergrowth with barite and marked negative $\mathrm{Ce}$ anomalies in carbonate attest the precipitation within a generally oxic environment, that is an environment not controlled by serpentinization. Strontium and $\mathrm{O}$ isotopic compositions in carbonate $\left({ }^{87} \mathrm{Sr} /{ }^{86} \mathrm{Sr}=0.7052\right.$ to $0.7054, \delta^{18} \mathrm{O}_{\mathrm{VSMOW}}=20$ to $24 \%$ ) imply precipitation from slab-derived fluids at temperatures between $\sim 130$ and $300^{\circ} \mathrm{C}$. These temperature estimates are consistent with the presence of blueschist facies phases such as lawsonite coexisting with the carbonates in some veins. Incorporated $\mathrm{C}$ is inorganic $\left(\delta^{13} \mathrm{C}_{\mathrm{VPDB}}=-1 \%\right.$ o
\end{abstract}

to $+4 \%$ ) and likely derived from the decarbonation of calcareous sediment and/or oceanic crust. These findings provide evidence for the mobilization of $\mathrm{C}$ in the downgoing slab at depths of $<20 \mathrm{~km}$. Our study shows for the first time in detail that a portion of this $\mathrm{C}$ forms carbonate precipitates in the subduction channel of an active convergent margin. This process may be an important asset in understanding the deep carbon cycle since it highlights that some $\mathrm{C}$ is lost from the subducting lithosphere before reaching greater depths.

\section{Introduction}

Subduction of oceanic lithosphere plays a crucial role in geochemical cycling on Earth, as subduction zones are a primary locus of transfers between exogenic and endogenic reservoirs. During subduction of $\mathrm{H}_{2} \mathrm{O}$ - and C-rich sediments as well as hydrated and carbonated lithosphere, a continuum of prograde diagenetic and metamorphic reactions in the downgoing slab drive its devolatilization and dehydration (e.g., Kerrick and Connolly, 2001; van Keken et al., 2002). The nature and extent of these processes determine the solubility of components in the slab-derived fluids and hence determine if elements are transported into the suprasubduction lithosphere or remain in the slab and are subducted deeply into Earth's mantle. 
The largest portion of $\mathrm{C}$ on Earth is stored in the lithosphere, and because subduction is the main route for recycling of this shallow $\mathrm{C}$, a thorough understanding of (de-)carbonation processes in the subduction channel is crucial to understanding Earth's carbon cycle (e.g., Sleep and Zahnle, 2001). Geochemical flux estimates of $C$ in convergent plate boundary settings have thus gained much attention in the recent past (e.g., Kerrick and Connolly, 2001; Newton and Manning, 2002; Gorman et al., 2006; Dasgupta and Hirschmann, 2010; Füri et al., 2010; Frezzotti et al., 2011; Sverjensky et al., 2014; Ague and Nicolescu, 2014; Kelemen and Manning, 2015; Piccoli et al., 2016; Barry et al., 2019). Yet, the fate of $\mathrm{C}$ in subduction zones remains unconstrained with recent mass balance estimates being extremely broad and suggesting that between $\ll 1$ and $\sim 80 \%$ of the 40 to $66 \mathrm{Mt} \mathrm{C}$ subducted per year is transported back into the convecting mantle (Kelemen and Manning, 2015).

Some insight into the deep carbon cycle is derived from studying magmatic products of arc volcanism. It has been shown that $\mathrm{C}$ is mobilized below volcanic arcs and transported into the upper plate's mantle and/or back into the atmosphere as $\mathrm{CO}_{2}$ in volcanic emissions (e.g., Kerrick and Connolly, 1998; Sleep and Zahnle, 2001; Blundy et al., 2010). However, these insights only reflect processes occurring at deep levels of subduction below depths of $70 \mathrm{~km}$, and the amount of $\mathrm{CO}_{2}$ emitted from arc volcanoes does not balance the amount of $\mathrm{C}$ initially being subducted (e.g., Dasgupta and Hirschmann, 2010; Kelemen and Manning, 2015). A significant portion of subducted $C$ must hence either be released from the downgoing slab before reaching these depths or it is transported to even greater depths (e.g., Kelemen and Manning, 2015). Geologic processes at both shallower (i.e., forearc) and greater depths (i.e., backarc) remain poorly understood since obtaining natural samples from these regions is not technologically possible. Insight into the shallow system, however, comes from the investigation of exhumed high-pressure metamorphic units and/or ophiolite sequences that commonly include obducted forearc materials (e.g., Frezzotti et al., 2011; Cook-Kollars et al., 2014; Falk and Kelemen, 2015; Piccoli et al., 2016; Schwarzenbach et al., 2018). The Oman ophiolite, for instance, exhibits extensive outcrops of listvenites, highly carbonated peridotites now composed of magnesite \pm dolomite + quartz (Falk and Kelemen, 2015). Carbon bound in these rocks is proposed to be derived from carbonate dissolution of subducted sediments (Falk and Kelemen, 2015); Kelemen and Manning (2015) hence proposed that the transfer of $\mathrm{CO}_{2}$ to the leading edge of the mantle wedge to form listvenite could represent an important process in forearc regions of convergent margins where substantial low-temperature $\left(<150^{\circ} \mathrm{C}\right)$ $\mathrm{C}$ transfer occurs. These observations are in line with experiments that demonstrate the increasing solubility of calcite in aqueous fluids with increasing pressure and temperature (Caciagli and Manning, 2003), suggesting that $C$ can be efficiently released from the downgoing slab even at relatively shallow levels, given that the conditions such as the fluid flux and the proportion of calcite in the slab are favorable. In the Costa Rican margin, for instance, Barry et al. (2019) suggest that more than $10 \%$ of the subducted $\mathrm{C}$ may be mobilized at forearc depths, as derived from studying $\mathrm{C}$ and $\mathrm{He}$ isotopes in hot springs from two transects across the forearc.

Slab-derived fluids that upwell in a number of serpentinite mud volcanoes at the deeply faulted Mariana forearc affirm the suggestion of carbonate breakdown at shallow subduction depths. The compositions of these fluids reflect prograde metamorphic processes in the subducting lithosphere and hence provide a direct, natural window into an active subduction system (e.g., Fryer et al., 1985, 1995; Hulme et al., 2010). In particular fluids upwelling at the deeperrooted mud volcanoes exhibit high carbonate alkalinities $\left(\mathrm{CO}_{3}^{2-}\right)$ and elevated concentrations of dissolved hydrocarbons $\left(\mathrm{CH}_{4}\right.$ and $\left.\mathrm{C}_{2} \mathrm{H}_{6}\right)$, indicative of decarbonation reactions in the downgoing plate at depths of $<30 \mathrm{~km}$ (Mottl et al., 2003; Hulme et al., 2010; Fryer et al., 2018b).

In peridotite-water systems, carbonate minerals can precipitate over a wide range of pressure and temperature conditions and in various natural settings. In shallow parts of the basement, carbonates can form during heating of seawater, cooling of hydrothermal fluids, mixing of hydrothermal fluids with seawater, and metasomatic replacement reactions (e.g., Bach et al., 2011; Klein et al., 2015; Schroeder et al., 2015; Grozeva et al., 2017); carbonation of peridotite may also occur under conditions similar to those of intermediate depths of forearc regions, as indicated by laboratory experiments at 1 to $2 \mathrm{GPa}$ and 500 to $600^{\circ} \mathrm{C}$ (Sieber et al., 2018). However, to date no carbonated mantle wedge peridotites have been identified from the serpentinite mud volcanoes in the Mariana forearc. Carbonate precipitates from serpentinite mud volcanoes so far described have mostly formed where upwelling fluids mixed with seawater near/at the seafloor (Haggerty et al., 1991; Gharib, 2006; Tran et al., 2014), except for few samples that are thought to have formed at temperatures of up to $250{ }^{\circ} \mathrm{C}$ from slab-derived fluids (Alt and Shanks III, 2006). The latter have not been studied in detail.

Here we have studied xenoliths brought to the seafloor along with fluids in the Mariana serpentinite mud volcanoes recovered during International Ocean Discovery Program (IODP) Expedition 366 (Fryer et al., 2018b). The samples investigated include metavolcanic and metasedimentary rocks as well as serpentinized peridotite. These rocks originate from the downgoing oceanic crust and from the upper plate's mantle, respectively. The clasts contain carbonate \pm silicate \pm sulfate veins, the genesis of which expands the knowledge into the subduction channel conditions and into the cycling of $\mathrm{C}$ in the shallow portions of the Mariana convergent margin. Geochemical and isotopic signatures of metavolcanic-hosted carbonates attest to mobilization of $\mathrm{C}$ from the downgoing plate and its re-precipitation in the form of $\mathrm{Ca}$ carbonates. Such carbonate formation below the "cold nose" of a convergent margin represents a sink for $\mathrm{C}$ in the 
deep carbon cycle that remains largely unquantified. Acrossforearc trends in upwelling fluid chemistry in the mud volcanoes (Fryer et al., 2018b) imply that decarbonation at depth may be widespread in the Mariana subduction system.

\section{Study area and materials}

Deep-rooted faults in the forearc of the non-accretionary Mariana subduction system act as pathways for upwelling fluids released from the subducting Pacific Plate (Fig. 1; Uyeda and Kanamori, 1979; Fryer et al., 1990; Phipps and Ballotti, 1992; Fryer, 1992, 1996, 2012). Together with mobilized serpentinite fault gouge these fluids rise through the mantle and crust of the Philippine Sea Plate to the seafloor, where they form more than a dozen active serpentinite mud volcanoes typically tens of kilometers in diameter and up to $2.5 \mathrm{~km}$ high (Fryer and Fryer, 1987; Fryer, 1992, 1996). These structures are chiefly composed of unconsolidated serpentinite mudflows with clasts of serpentinized forearc mantle peridotite and other rare xenoliths including sediments and mafic rocks derived from the subducted Pacific Ocean crust (e.g., Maekawa et al., 1995; Fryer et al., 1999, 2018b). The mud volcanoes are found at a range of distances from the trench. Consequently, these structures sample the subducting slab and location of fluid release at increasing depth and thus variable pressure and temperature conditions (e.g., Oakley et al., 2007; Hulme et al., 2010). The mud volcanoes in the Mariana forearc hence provide direct access to sourced fluids and materials from the subduction channel and suprasubduction zone and unique insight into shallow subduction zone processes. There is tentative evidence that serpentinite mud volcanism could have occurred as early as the Archean (Pons et al., 2011), implying that such processes may have been prevalent throughout Earth history.

Five serpentinite mud volcanoes have been targeted by three ocean-drilling campaigns: Yinazao $(55 \mathrm{~km}$ distance from the trench, $13 \mathrm{~km}$ slab depth, slab temperature $\sim 80^{\circ} \mathrm{C}$ ), Fantangisña $(62 \mathrm{~km}$ from the trench, $14 \mathrm{~km}$ slab depth, $\left.150^{\circ} \mathrm{C}\right)$, Asùt Tesoru $(72 \mathrm{~km}$ from the trench, $18 \mathrm{~km}$ slab depth, $\left.\sim 250{ }^{\circ} \mathrm{C}\right)$, South Chamorro $(78 \mathrm{~km}$ from the trench, $18 \mathrm{~km}$ slab depth, $\left.\sim 250-350^{\circ} \mathrm{C}\right)$, and Conical $(86 \mathrm{~km}$ distance from the trench, $19 \mathrm{~km}$ slab depth, $\sim 250-350{ }^{\circ} \mathrm{C}$; Maekawa et al., 1993; Fryer and Salisbury, 2006; Gharib, 2006; Oakley et al., 2007, 2008; Hulme et al., 2010). We studied drill core materials recovered from Yinazao, Fantangisña, and Asùt Tesoru during IODP Expedition 366. Our samples include (i) rock clasts of serpentinized peridotite, altered mafic volcanics, and metasediment; (ii) authigenic carbonate precipitates from the serpentinite mud; and (iii) pore waters extracted from the serpentinite mud. Veins of carbonate, silicate, and sulfate phases crosscut the rock clasts.

\section{Methodology}

Visual observations were conducted in thin section with both a standard petrographic microscope and a scanning electron microscope. Detailed mineralogical and geochemical analyses of mineral assemblages were carried out on thin sections using confocal Raman spectroscopy, electron microprobe analyses, and laser ablation inductively coupled plasma mass spectrometry (ICP-MS). Stable and Sr isotopic compositions were determined on hand-picked mineral separates of vein materials.

\subsection{In situ analyses}

\subsubsection{Confocal Raman spectroscopy}

Mineral assemblages were analyzed with a computercontrolled Horiba LabRAM HR confocal Raman microscope at the Woods Hole Oceanographic Institution. The device is equipped with three lasers $(473,532$, and $633 \mathrm{~nm})$; two gratings (600 and 1800 grooves $\left.\mathrm{mm}^{-1}\right)$; a thermoelectric cooled $\left(-70{ }^{\circ} \mathrm{C}\right) \mathrm{CCD}$ detector; $4 \times, 10 \times, 50 \times$, and $100 \times$ objectives; a $x-y-z$ motorized stage; and automated mapping options. Most spectra were collected using the $633 \mathrm{~nm}$ laser and the 600 grooves $\mathrm{mm}^{-1}$ grating for 5 to $10 \mathrm{~s}$ with three to five accumulations between 100 and $1280 \mathrm{~cm}^{-1}$. The LabSpec 6 software suite was used for post-processing of acquired spectra. The instrument was calibrated daily using a silicon wafer, and the RRUFF Raman database (Lafuente et al., 2016) was used for phase identification.

\subsubsection{Electron microprobe analyses}

Elemental compositions of minerals were obtained with a CAMECA SX100 electron microprobe at the University of Bremen. Silicates were analyzed for $\mathrm{Si}, \mathrm{Ti}, \mathrm{Al}, \mathrm{Cr}, \mathrm{Mg}, \mathrm{Fe}$, $\mathrm{Mn}, \mathrm{Ca}, \mathrm{Na}$, and $\mathrm{K}$ and carbonates for $\mathrm{Si}, \mathrm{Mg}, \mathrm{Ca}, \mathrm{Mn}, \mathrm{Fe}$, $\mathrm{Sr}$, and $\mathrm{Ba}$. The instrument is equipped with four wavelength dispersive spectrometers. Analytical conditions included an accelerating voltage of $15 \mathrm{kV}$ and beam currents of $10 \mathrm{nA}$ for silicates and $8 \mathrm{nA}$ for carbonates. Peak counting times varied between 20 and $40 \mathrm{~s}$ per element, and analyses were carried out with a fully focused beam (silicates) and $5 \mu \mathrm{m}$ defocused beam (carbonates). The built-in PAP correction was applied for data reduction and correction. Natural silicate and carbonate standards were analyzed together with the samples to guarantee data accuracy. For most elements with concentrations $>1 \mathrm{wt} \%$, averaged precision is better than $2 \%$ and averaged accuracy is better than $5 \%$.

\subsubsection{Laser ablation ICP-MS}

Analyses of trace elements (B, Mn, Rb, Sr, Y, Cs, Ba, and rare earth elements) were carried out using a Thermo Finnigan Element2 ICP-MS coupled to a New Wave UP193 solidstate laser ablation system at the University of Bremen. An- 


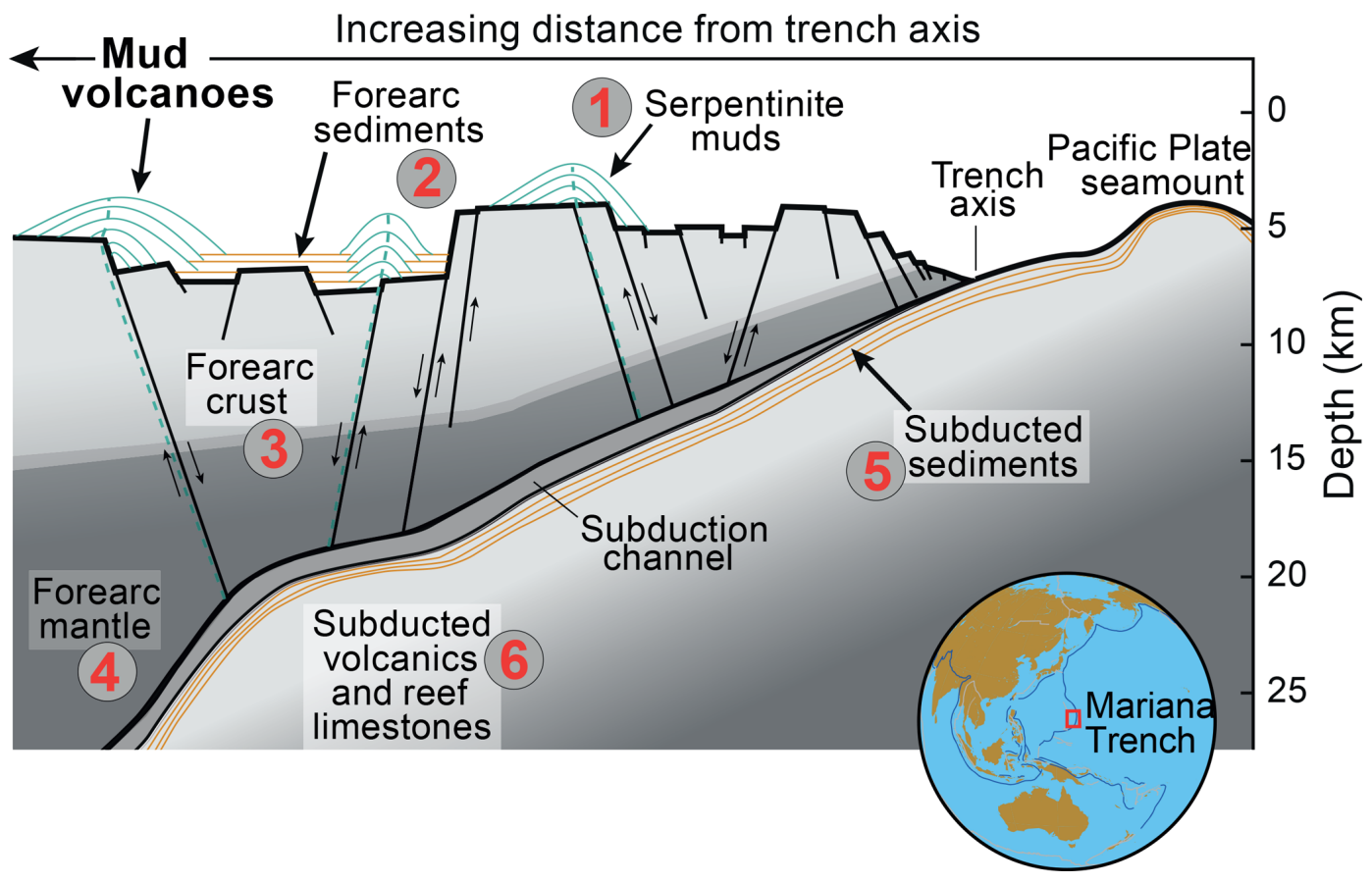

Figure 1. Geotectonic setting of the study area. Idealized cross section of the Mariana forearc, including the relative positioning of serpentinite mud volcanoes drilled during IODP Expedition 366. Sediments (5) and crustal rocks (6) from the downgoing plate are reworked in the shallow subduction zone and are, together with materials from the forearc lithosphere (2-4), erupted within the serpentinite mudflows (1). Figure modified from Fryer et al. (2018b).

alytical conditions included an irradiance of $\sim 1 \mathrm{GW} \mathrm{cm}^{-2}$ for ablation, spot sizes of 75 to $100 \mu \mathrm{m}$, and a laser pulse rate of $5 \mathrm{~Hz}$. Helium $\left(0.7 \mathrm{~L} \mathrm{~min}^{-1}\right)$ and $\mathrm{Ar}\left(0.9 \mathrm{~L} \mathrm{~min}^{-1}\right)$ were used as sample and make-up gases, respectively. All isotopes were analyzed at low resolution with five samples in a $20 \%$ mass window and a total dwell time of $25 \mathrm{~ms}$ per isotope. After every 4 to 8 samples the glass standard NIST SRM 610 was measured for external calibration using the values from Jochum et al. (2011). To correct for interferences between ${ }^{43} \mathrm{Ca}$ and ${ }^{86} \mathrm{Sr}^{2+}$ we determined the quantitative relationship between ${ }^{86} \mathrm{Sr}^{2+}$ and ${ }^{88} \mathrm{Sr}$ in an in-house Ca-free but Sr-containing glass standard; the abundance of ${ }^{86} \mathrm{Sr}^{2+}$ is about $1.7 \%$ of that of ${ }^{88} \mathrm{Sr}$, which is considered to mirror its natural isotopic existence. For all analyses we hence subtracted $1.7 \%$ of the intensity counts per second of ${ }^{88} \mathrm{Sr}$ from that of ${ }^{43} \mathrm{Ca}$. The ${ }^{43} \mathrm{Ca}$ isotope was used as internal standard and concentrations were calculated with the Cetac $\mathrm{GeoPro}^{\mathrm{TM}}$ software. We tentatively assigned a detection limit of $0.001 \mu \mathrm{g} \mathrm{g}^{-1}$ for rare earth elements (REEs) and $\mathrm{Y}$ as their detection limits are not well defined due to their low blanks. Such low concentrations correspond to only a few counts per second for some elements, which results in relative standard deviations as high as $50 \%$. Analytical quality was controlled by repeated analyses of USGS reference materials BRC-2G, BHVO-2G, and MACS-3 and comparison of our data with the GeoReM database (as of February 2018). For the three reference materials, averaged precisions are better than $7.5 \%$ except for Ho and Tm (better than 10\%). Averaged accuracies of BCR-2G and BHVO-2G are better than $6 \%$ except for $\mathrm{Tm}$ and $\mathrm{Yb}$ (up to $10.5 \%$ ); averaged accuracy of MACS3 is better than $10 \%$ except for Gd, Dy, Ho, Er, and Lu (all better than $15 \%$ ).

\subsection{Isotope analyses}

\subsubsection{Carbonate}

Vein material was separated from the individual clasts mechanically by hand and crushed with a mortar and pestle to provide representative material of the bulk composition of the vein carbonates. Carbonate minerals were hand-picked for isotope analyses from the crushed vein material.

\section{Carbon and oxygen}

Hand-picked carbonate minerals were washed with deionized water and cleaned in an ultrasonic bath. The $\mathrm{O}$ and $\mathrm{C}$ stable isotope compositions of the cleaned vein carbonate samples were measured on a ThermoScientific MAT 253 connected to a Kiel V, and authigenic carbonate samples were analyzed on a Finnigan MAT 251 gas isotope ratio mass spectrometer connected to a Kiel I automated carbonate preparation device at MARUM. Carbon isotopes are reported in the usual delta notation versus VPDB; O isotopes are reported versus VSMOW. The instrument was calibrated 
against the house standard (ground Solnhofen limestone), which in turn was calibrated against the NBS 19 standard reference material. Over the measurement periods the standard deviation of the house standard was $0.06 \%$ for $\delta^{13} \mathrm{C}$ values and $0.11 \%$ for $\delta^{18} \mathrm{O}$ values for the Thermo Fischer and $0.04 \%$ for $\delta^{13} \mathrm{C}$ and $0.03 \%$ for $\delta^{18} \mathrm{O}$ for the Finnigan instrument.

\section{Strontium}

For the analyses of $\mathrm{Sr}$ isotopes, approximately $2 \mathrm{mg}$ of homogenized carbonate powder was dissolved in $2 \mathrm{M} \mathrm{HNO}_{3}$, dried, and redissolved in $500 \mu \mathrm{L}$ of $2 \mathrm{MHNO}_{3}$ in preparation for the chemical separation of $\mathrm{Sr}$ from unwanted matrix elements. Strontium was extracted using columns loaded with ca. $70 \mu \mathrm{L}$ of Sr-spec ion exchange resin (Triskem International) following a procedure adapted from Deniel and Pin (2001). The Sr was loaded on single Re filaments with Ta-oxide emitter and analyzed by ThermoScientific TritonPlus TIMS (thermal ionization mass spectrometry) in the multidynamic acquisition mode at MARUM. The ${ }^{87} \mathrm{Sr} /{ }^{86} \mathrm{Sr}$ ratios were normalized to a ${ }^{86} \mathrm{Sr} /{ }^{88} \mathrm{Sr}$ ratio of 0.1194 to correct for instrumental mass fractionation. The long-term external reproducibility of the NIST SRM 987 standard material was $0.710249 \pm 0.000014(2 \sigma, n=220)$ and falls within the range of $0.710250 \pm 0.000034(2 \sigma, n=1245$; data $<0.7102$ and $>0.7103$ are discarded) of published NIST SRM 987 values analyzed by TIMS (GeoReM database, as of September 2017).

\subsubsection{Sulfate}

\section{Sulfur and oxygen}

The $\mathrm{S}$ and $\mathrm{O}$ isotope compositions of barite were analyzed at the University of Münster. Prior to the analyses, the barite was treated with $\mathrm{HCl}(10 \%)$ to remove intergrown carbonate, cleaned, and dried. For $\mathrm{S}$ isotope measurements $\left({ }^{34} \mathrm{~S} /{ }^{32} \mathrm{~S}\right)$, an aliquot of $400 \mu \mathrm{g}$ of barite was homogeneously mixed with 400 to $600 \mu \mathrm{g}$ vanadium pentoxide $\left(\mathrm{V}_{2} \mathrm{O}_{5}\right)$ in a tin capsule. Sulfur isotopes were measured with an EA-IRMS (element analyzer isotope ratio MS) with a combination of EA IsoLink $^{\mathrm{TM}}$ and ThermoScientific Delta V Advantage MS. For oxygen isotopes, $200 \mu \mathrm{g}$ barite was weighted into an Ag capsule. Analyses were carried out with a temperature conversion/EA interfaced with a ThermoScientific Delta V Plus MS. Oxygen isotope compositions are reported in the common delta notation versus VSMOW. Replicates were measured for both $\delta^{34} \mathrm{~S}$ and $\delta^{18} \mathrm{O}$ and the accuracy of the measurements was monitored using the international reference materials IAEA-S1, IAEA-S2, IAEA-S3, and NBS 127 for S and IAEA-SO5, IAEA-SO6, and NBS 127 for O as well as internal reference materials $\mathrm{Ag}_{2} \mathrm{~S}$ and $\mathrm{CdS}$ for $\mathrm{S}$ and $\mathrm{BaSO}_{4}$ for $\mathrm{O}$. Reproducibility as determined from replicate analy- ses was better than $\pm 0.3 \%$ for $\mathrm{S}$ and $\pm 0.5 \%$ o for $\mathrm{O}$ isotope measurements.

\subsubsection{Pore waters}

\section{Strontium}

Pore waters were sampled from the serpentinite mud volcanoes during IODP Expedition 366 following onboard methods described in Fryer et al. (2018a). Preparation for the analysis of $\mathrm{Sr}$ isotopes was undertaken in the University of Southampton's class 100 clean laboratories. Subsamples of pore waters were taken to contain sufficient $\mathrm{Sr}$ for isotope measurement, and $\mathrm{Sr}$ was separated from dissolved matrix elements using Sr-spec resin following Harris et al. (2015). The Sr was loaded on Ta filaments with Ta-oxide emitter and measured on a ThermoScientific TritonPlus TIMS in the multidynamic acquisition mode at the University of Southampton. External reproducibility was assessed using international reference material: the average value for ${ }^{87} \mathrm{Sr} /{ }^{86} \mathrm{Sr}$ of NIST SRM 987 was $0.710244 \pm 0.000019(2 \sigma$, $n=135$ ).

\subsection{Geothermometry}

Carbonate formation temperatures were calculated based on the $\mathrm{O}$ isotopic compositions of carbonates and of the solutions from which these precipitated. For the carbonates formed within the subduction channel, we used the calibrations from O'Neil et al. (1969) and Friedman and O'Neil (1977). The latter was as well used for the single calcite sample that was recovered from Asùt Tesoru, whereas the calibration curve from Grossman and $\mathrm{Ku}$ (1986) was used for authigenic aragonite formed within the Yinazao mud volcano.

\section{Results}

\subsection{Host rocks}

Host rocks of the carbonate \pm silicate \pm sulfate veins are ultramafic, metavolcanic, and metasedimentary clasts. Metavolcanic and metasedimentary clasts originate exclusively from the deeper-sourced mud volcanoes Fantangisña and Asùt Tesoru, whereas ultramafic hosts were recovered at Asùt Tesoru and the shallow-sourced Yinazao (Table 1).

Studied peridotites include two samples of dunite and one sample of harzburgite. One of the dunites is about $30 \%$ serpentinized, whereas the other peridotites are fully serpentinized and characterized by mesh textures and distinct generations of crosscutting serpentine \pm brucite \pm magnetite veins (Fig. S1 in the Supplement). The harzburgite contains hydroandradite intergrown with serpentine in bastite texture after pyroxene (Fig. S1b) and scarce late veins that contain carbonate phases. 
Table 1. Overview on samples and vein mineralogies.

\begin{tabular}{llllll}
\hline Sample & Seamount & Type & $\begin{array}{l}\text { Vein } \\
\text { mineralogy }\end{array}$ & $\begin{array}{l}\text { Carbonate } \\
\text { formation }\end{array}$ & Comment \\
\hline U1491B-5H-CC, 0-3 cm & Yinazao & Serp. dunite & Cal, Arg, Hem & Shallow & Partly serpentinized mantle wedge \\
U1492B-1H-3, 16-18cm & Yinazao & Authigenic & Arg & Shallow & Acicular growth \\
U1492B-1H-4, 8-10 cm & Yinazao & Authigenic & Arg & Shallow & Acicular growth \\
U1492C-1H-2, 18-20 cm & Yinazao & Serp. harzburgite & Cal, Brc, Mt & Shallow & Fully serpentinized mantle wedge \\
U1497A-7X-CC, 29-31 cm & Fantangisña & Metasediment & Arg, Cal, Brt & Deep & Recycled lithified siliceous ooze \\
U1497A-8F-1, 118-122 cm & Fantangisña & Metavolcanic & None & n/a & Recycled basalt (tholeiitic to alkaline) \\
U1497A-12F-1, 93-95 cm & Fantanginña & Metavolcanic & Cal & Deep & Recycled basalt (alkaline) \\
U1498B-8R-1, 0-4 cm & Fantangisña & Metavolcanic & Cal, Nsq, Pct, Prh, Thm & Deep & Recycled basalt (tholeiitic to alkaline) \\
U1498B-8R-1, 10-15 cm & Fantanginña & Metavolcanic & Arg, Cal, Pct & Shallow & Recycled basalt (alkaline); late calcite vein \\
U1498B-8R-1, 32-34 cm & Fantangisña & Metavolcanic & Cal, Pct, Prh & Deep & Recycled basalt (tholeiitic to alkaline) \\
U1495B-5G-CC, 1-3cm & Asùt Tesoru & Serp. dunite & Cal, Arg & Shallow & Fully serpentinized mantle wedge \\
U1496A-10G-CC, $23-26 \mathrm{~cm}$ & Asùt Tesoru & Metavolcanic & Pct & n/a & Recycled basalt (tholeiitic to alkaline) \\
U1496B-4F-3, 105-106 cm & Asùt Tesoru & Authigenic & Cal & Shallow & Euhedral crystal \\
U1496B-8X-CC, $33-41 \mathrm{~cm}$ & Asùt Tesoru & Metavolcanic & Arg, Ms, Lws, Ttn & Deep & Recycled basalt (alkaline) \\
U1496B-10F-2, 10-12 cm & Asùt Tesoru & Metavolcanic & Arg, Nsq & Deep & Recycled basalt (tholeiitic to alkaline) \\
\hline
\end{tabular}

The basalt type of the metavolcanic samples is exclusively based on Ti and $\mathrm{Ca}+\mathrm{Ni}$ contents in clinopyroxene in the respective samples (cf. Fig. 2e). Abbreviations: Arg, aragonite; Brc, brucite; Brt, barite; Cal, calcite; Hem, hematite; Lws, lawsonite; Ms, muscovite; Mt, magnetite; n/a, not available; Nsq, nesquehonite; Pct, pectolite; Prh, prehnite; serp., serpentinized; Thm, thaumasite; Ttn, titanite; n/a, not applicable.

Seven variably metamorphosed volcanic rocks (Fig. 2a; Table 1) contain relict primary minerals including lathshaped plagioclase and titaniferous clinopyroxene (Fig. 2ac). The Ti-rich pyroxenes mostly plot in the field of alkali basalt, as classified by Leterrier et al. (1982; Fig. 2e). The primary mineral assemblages were largely altered to prehnitepumpellyite and blueschist facies mineral assemblages, including chlorite, prehnite, pumpellyite, glaucophane, lawsonite, titanite, and vesuvianite (representative analyses available in Table S1 in the Supplement). These samples are characterized by complex networks of carbonate-silicate veins.

The metasedimentary quartzite is brecciated into smaller fragments in a fine-grained matrix that is rich in calcite and hematite (Fig. 2d). Fine calcite veins crosscut the quartz fragments; the breccia is crosscut by a centimeter-wide vein of aragonite, calcite, and barite.

\subsection{Mineral assemblages in veins}

\subsubsection{Petrography}

Distinct vein generations crosscut the clasts and comprise (i) carbonate-silicate, (ii) silicate-only, or (iii) carbonatesulfate vein types (Table 1). The veins most commonly dissect grain boundaries, are of kinked to irregular shape, and rarely show branching geometries (cf. Shipboard Scientific Party, 2004). The vein minerals mostly exhibit euhedral grain shapes and lack signs of deformation.

Carbonate-silicate veins hosted by variably serpentinized peridotite are $<0.5 \mathrm{~mm}$ wide and crosscut most other textures, indicating a late formation (Fig. 3a). Carbonate phases are calcite and aragonite with grain sizes of up to $\sim 0.3 \mathrm{~mm}$. Both phases can occur in the same sample
(Fig. 3a); in one clast they coexist in the same vein. Serpentine \pm iowaite \pm minor magnetite and hematite coexist with the carbonates in the veins. Iowaite can show needle-like textures suggestive of growth in open fractures (Fig. S1).

The veins in metavolcanic clasts can be up to $1 \mathrm{~cm}$ wide and commonly overprint earlier textures (Fig. 3b, c). The most abundant vein minerals are aragonite, calcite (less abundant than aragonite), pectolite, and prehnite; some veins contain minor lawsonite, nesquehonite, phengite, and thaumasite (see Table 1 and Fig. $3 \mathrm{f}$ for Raman spectra of vein minerals). The proportions of these phases are highly variable throughout the individual samples. Aragonite grains are up to $\sim 1 \mathrm{~mm}$ in size. Calcite is generally $<0.25 \mathrm{~mm}$ or microcrystalline. Carbonates and silicates generally occur intergrown or with straight crystal contacts indicative of chemical equilibrium. The silicate minerals, in particular pectolite, show radial growth in many cases (Fig. 3c). These crystallization patterns are indicative of growth in open fractures. At least two generations of carbonate are observed in some samples (e.g., sample U1498B-8R, 10-15 cm, where calcite and pectolite overgrow earlier aragonite; Fig. 3c). Veins in metavolcanic sample U1498B-8R-1, 32-34 cm, consist of pectolite and prehnite except for a narrow $(<1 \mathrm{~mm})$ vein of pure calcite, crosscutting all other textures (Fig. 3b). Metavolcanic sample U1498B-8R-1, 0-4 cm, contains veins of pectolite, prehnite, and minor mostly microcrystalline calcite. Late veinlets of nesquehonite \pm thaumasite are present in two samples (U1496B-10F-2, 10-12 cm, and U1498B$8 \mathrm{R}-1,0-4 \mathrm{~cm}$ ). Two other metavolcanic clasts do not exhibit any carbonate-bearing veins, but one shows veins of pectolite in radiating crystal clusters (sample U1496A-10G-CC, $23-26 \mathrm{~cm}$ ), whereas the other is not veined (U1497A-8F-1, $118-122 \mathrm{~cm}$; see Table 1). 

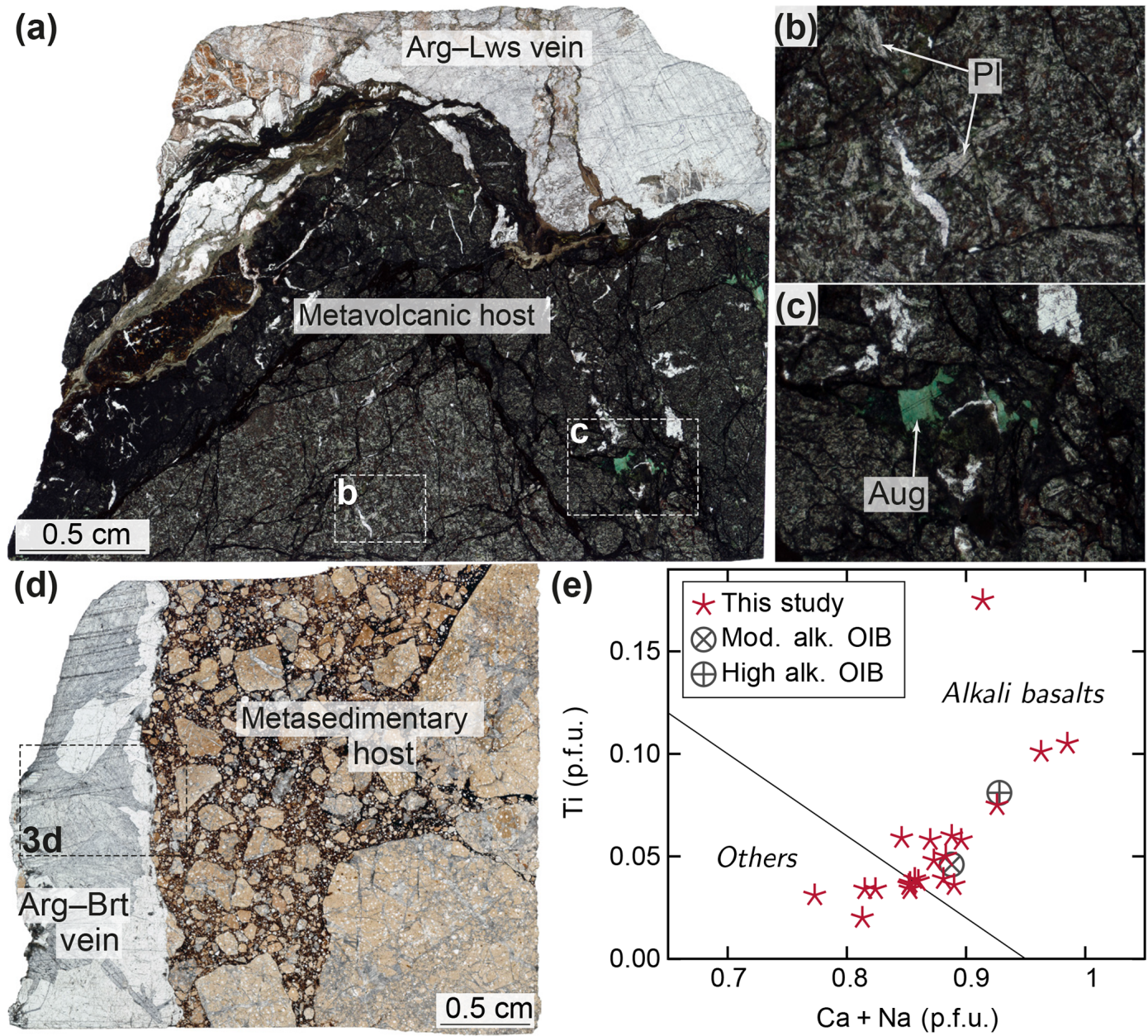

Figure 2. Thin section scans and photomicrographs showing host lithologies. (a) Thin section scan of a metavolcanic clast interpreted as subducted and recycled Pacific Plate seamount material (sample U1496B-8X-CC, 33-41 cm). A carbonate-silicate vein crosscuts the clast. Close-ups show (b) remnant primary plagioclase lath textures and (c) titaniferous clinopyroxene inside the metavolcanic rock. Representative analyses of metamorphic phases within the metavolcanic clasts are shown in Table S1. (d) Thin section scan of a metasedimentary clast representing subducted and recycled Pacific Plate sediment (sample U1497A-7X-CC, 29-31 cm). The sample is cut by a carbonate-sulfate vein (close-up in Fig. 3d). (e) Discrimination diagram for clinopyroxene phenocrysts (following Leterrier et al., 1982). Many clinopyroxenes from the metavolcanic samples plot in the field of alkali basalts (calculated on the basis of 6 O). Averaged basalt compositions are shown for comparison (as compiled by Leterrier et al., 1982). Abbreviations: alk., alkaline; Arg, aragonite; Aug, augite; Brt, barite; Lws, lawsonite; mod., moderately; OIB, ocean island basalt; Pl, plagioclase.

The quartzite sample (U1497A-7X-CC, 29-31 cm) has millimetric aragonite and barite crystals in a millimeter-wide vein (Fig. 3d, Table 1). Intergrowth of aragonite and barite suggests co-crystallization in equilibrium with a fluid. The vein further hosts one $\sim 200 \mu \mathrm{m}$ long calcite crystal extending into the barite. Barite has not previously been observed in the eruptive products of the Mariana serpentinite mud volcanoes.

In addition to vein carbonates in the clasts, we sampled authigenic carbonates contained in the serpentinite mud matrix (Table 1). At Yinazao, acicular aragonite crystals up to $4 \mathrm{~mm}$ in length were scattered throughout the drill core (Fig. 3e). At Asùt Tesoru, calcite crystals with euhedral shapes and diam- eters of up to $5 \mathrm{~mm}$ occurred disseminated in the mud matrix. The euhedral growth of both aragonite and calcite implies in situ precipitation of these minerals in the mud matrix, as previously interpreted by Fryer et al. (2018c, d, e).

\subsubsection{Mineral chemistry}

Major and trace elemental compositions in the carbonates are highly variable. Magnesium and $\mathrm{Fe}$ concentrations in calcite vary from $<10 \mu \mathrm{g} \mathrm{g}^{-1}$ to up to $\sim 14000 \mu \mathrm{g} \mathrm{g}^{-1}$ and $\sim 1600{\mu \mathrm{g} \mathrm{g}^{-1}}^{-1}$, respectively. Serpentinite-hosted calcite exhibits the highest $\mathrm{Mg}$ contents, whereas the Mg concentrations in aragonite and calcite hosted by metavolcanic and the metasedimentary clasts are below $8500 \mu \mathrm{g} \mathrm{g}^{-1}$. Accord- 


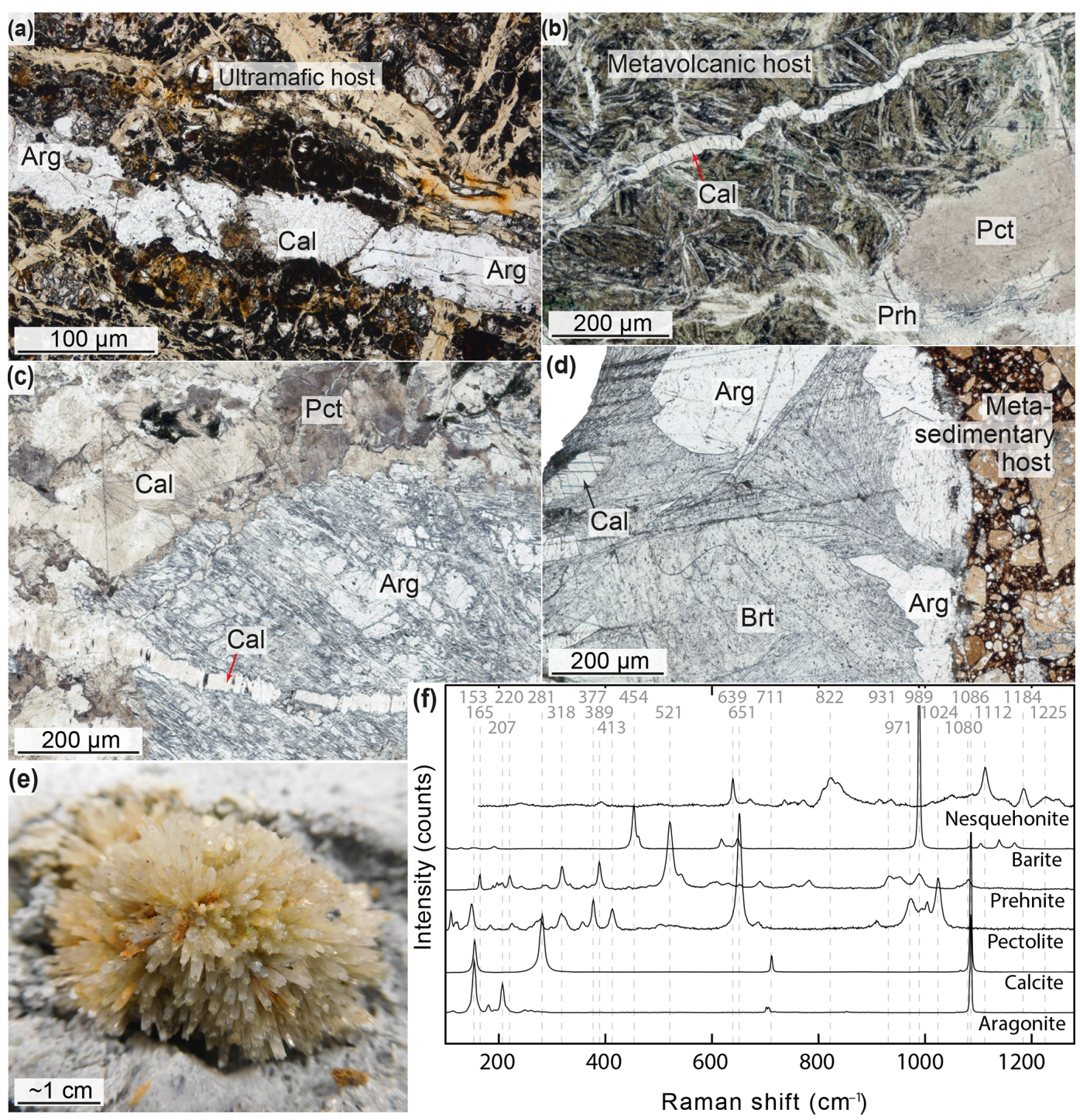

Figure 3. Thin section scans and photomicrographs depicting vein assemblages. (a) Late-stage calcite-aragonite vein in partially serpentinized ultramafic clast (sample U1491B-5H-CC, 1-3 cm). (b) Narrow late-stage calcite vein in metavolcanic host rock (sample U1498B-8R1, 32-34 cm). (c) Wide vein inside metavolcanic clast with complex intergrowth of pectolite and microcrystalline calcite overgrowing earlier aragonite (sample U1498B-8R-1, 10-15 cm). (d) Wide barite-aragonite-calcite vein in a brecciated quartzite clast (sample U1497A-7X-CC, 29-31 cm). Euhedral crystal shapes imply a strain-free environment and chemical equilibrium during precipitation. (e) Authigenic aragonite with acicular growth within serpentinite mudflow (sample U1492B-1H-3, 16-18 cm). (f) Raman spectra of the most common carbonate, silicate, and sulfate vein assemblages. Abbreviations: Arg, aragonite; Brt, barite; Cal, calcite; Pct, pectolite; Prh, prehnite.

ingly, $\mathrm{Mg} / \mathrm{Ca}$ ratios are variable and range up to 0.022 for the latter-mentioned vs. values up to 0.038 for carbonates in serpentinite. Strontium concentrations vary from $<30$ to $\sim 15000 \mu \mathrm{gg}^{-1}$ and $\mathrm{Sr} / \mathrm{Ca}$ ratios from $<0.001$ to $\sim 0.04$. Aragonite has highest $\mathrm{Sr}$ concentrations but concentrations can also be low $\left(<1200 \mu \mathrm{g} \mathrm{g}^{-1}\right)$. Aragonite further reveals variable $B$ concentrations $\left(0.5-34 \mu \mathrm{g} \mathrm{g}^{-1}\right.$, mean $\left.=4.9 \mu \mathrm{g} \mathrm{g}^{-1}, n=34\right)$; by comparison, B contents in calcite are much lower $\left(0.3-6.2 \mu \mathrm{g} \mathrm{g}^{-1}\right.$, mean $=1.4 \mu \mathrm{g} \mathrm{g}^{-1}$, $n=24)$. Yttrium concentrations are low in aragonite $(<0.1-$ $4.4 \mu \mathrm{g} \mathrm{g}^{-1}$, mean $\left.=0.4 \mu \mathrm{gg}^{-1}\right)$ but range up to $8.6 \mu \mathrm{g} \mathrm{g}^{-1}$ in calcite $\left(\right.$ mean $\left.=2.4 \mu \mathrm{g} \mathrm{g}^{-1}\right)$. The chondrite-normalized $\mathrm{REE}+\mathrm{Y}$ patterns of aragonite and calcite are indistinguishable within individual samples (chondrite composition from McDonough and Sun, 1995). Distinct variations in carbonate REE + Y systematics are, however, observed as a function of the respective host lithologies (Fig. 4; see also Fig. S2 for a per-sample illustration of metavolcanic- and metasedimenthosted carbonates). Chondrite-normalized REE + Y patterns of carbonates hosted by serpentinite clasts or the serpentinite mud are flat or slightly enriched in heavy REEs (HREES), and concentrations are below chondritic (highest Lu value 


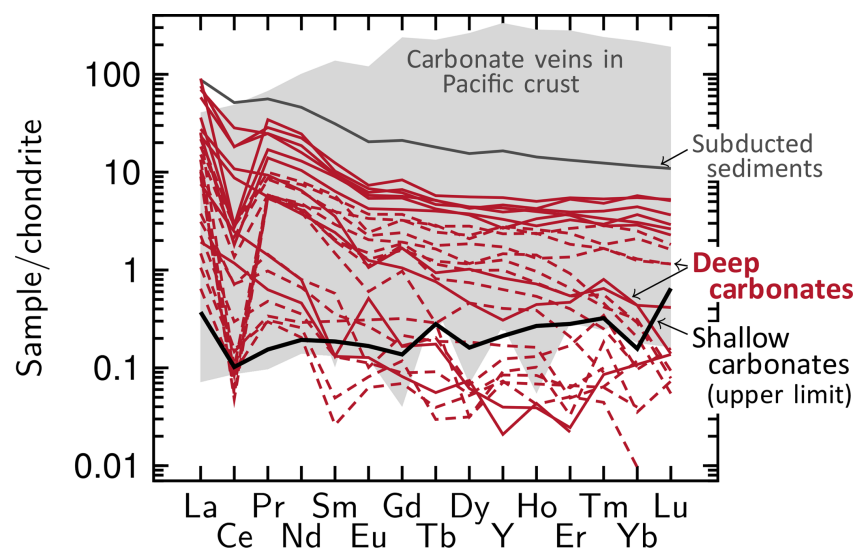

Figure 4. Chondrite-normalized (McDonough and Sun, 1995) $\mathrm{REE}+\mathrm{Y}$ compositions of vein carbonates. Carbonates formed from deep fluids (red lines) are enriched in REEs and exhibit negative $\mathrm{Ce}$ anomalies. They are hosted by metavolcanic clasts and a quartzite breccia. Samples are from Fantangisña (dashed lines) and Asùt Tesoru (solid lines). Carbonates formed close to the seafloor have low REE contents (the bold black line marks the upper limit of REE contents across all authigenic carbonates and carbonates within serpentinite clasts) and likely precipitated from mixed venting fluid and seawater. These carbonates are hosted by serpentinite and one metavolcanic clasts and also include carbonates that grew in the mud matrix. For comparison, REE data of carbonate veins in the basaltic Pacific crust (ODP Site 801 and Site 1149; Rausch, 2012) and of subducting sediments (ODP Site 800 and Site 801; Plank and Langmuir, 1998) are shown.

is $<0.7$ times chondritic). Chondrite-normalized $\mathrm{La} / \mathrm{Lu}$ ratios range from 0.3 to 22.3 . Contrastingly, carbonate phases hosted by metavolcanic clasts and the quartzite have generally higher REE $+\mathrm{Y}$ concentrations and show a strong depletion in HREEs, with Lu depletion over La of $<0.001$ to 0.84 . The patterns of these vein minerals commonly show negative $\mathrm{Ce}$ anomalies with $\mathrm{Ce} /(\mathrm{La} \cdot \mathrm{Pr})^{0.5}$ of 0.01 to 1.18 . Because these carbonates are commonly associated with highpressure phases, such as lawsonite, we will refer to the carbonates with high light REE (LREE) concentrations as "deep carbonates" and to the REE-low carbonates as "shallow carbonates" (Fig. 4). Representative chemical analyses are presented in Table 2.

\subsubsection{Isotopic compositions}

Strontium isotopic ratios $\left({ }^{87} \mathrm{Sr} /{ }^{86} \mathrm{Sr}\right)$ have a narrow range from 0.70523 to 0.70538 in deep carbonates and from 0.70495 to 0.70644 in shallow carbonates (Fig. 5, Table 3). Strontium concentrations in pore water samples from Yinazao, Fantangisña, and Asùt Tesoru serpentinite mud volcanoes are variable. With up to $\sim 690 \mu \mathrm{M} \mathrm{Sr}$, fluids ascending at the shallower-sourced Yinazao are considerably enriched relative to bottom seawater $(90 \mu \mathrm{M}$; Mottl et al., 2004), whereas those at deep-sourced Asùt Tesoru are strongly de-

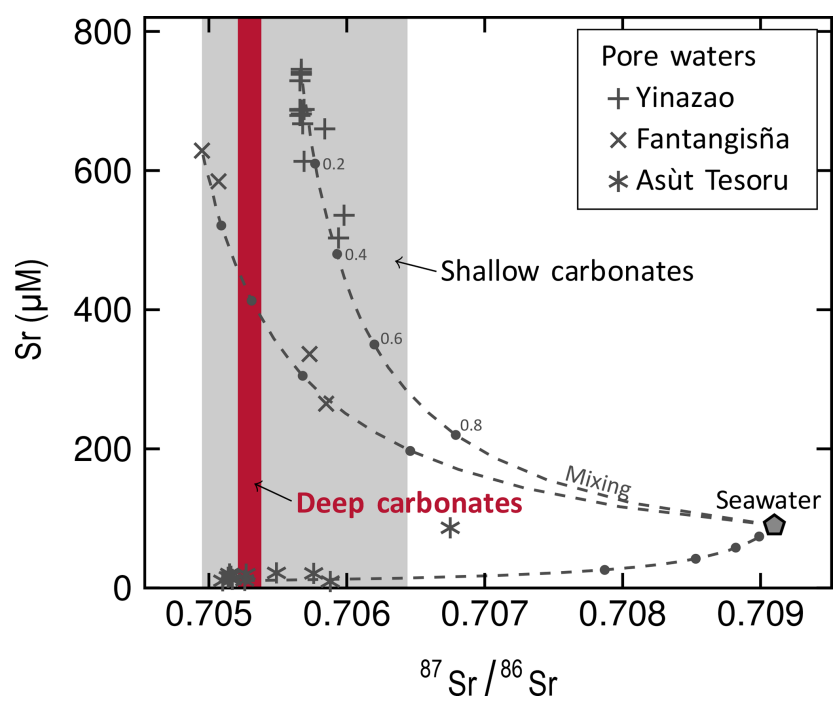

Figure 5. Strontium geochemistry of carbonates and serpentinite mud pore waters. Slab-derived fluids (pore waters) generally are more unradiogenic than seawater but show mixing with seawater as indicated by pore water samples plotting on the mixing lines. Mixing usually occurs towards the core tops (cf. Table S2). Strontium isotope ratios of deep carbonates well resemble the more unradiogenic signatures of the slab-derived fluids, implying that they precipitated from such fluids at depth. Shallow carbonates exhibit a wider range of $\mathrm{Sr}$ isotopic compositions. They likely formed in the mixing zone of upwelling fluids and seawater. Note that even large amounts of seawater admixed into slab-derived fluids do not necessarily alter the $\mathrm{Sr}$ isotopic composition strongly (numbers along the mixing lines indicate the fraction of seawater). Bottom seawater composition from Mottl et al. (2004).

pleted ( $<22 \mu \mathrm{M}$; Fig. 5, Table S2). The pore fluids range in ${ }^{87} \mathrm{Sr} /{ }^{86} \mathrm{Sr}$ from 0.70566 to 0.70598 at Yinazao, from 0.70495 to 0.70585 at Fantangisña, and from 0.70510 to 0.70675 at Asùt Tesoru. The pore waters from the deepest sections of the individual bore holes usually exhibit the most unradiogenic values and the upper sections show increasing mixing with radiogenic modern seawater $\left({ }^{87} \mathrm{Sr} /{ }^{86} \mathrm{Sr}=0.7091\right.$; Mottl et al., 2004; Fig. 5).

Carbonate $\delta^{13} \mathrm{C}$ values range from $-0.6 \%$ to $+3.3 \%$ o VPDB (Fig. 6, Table 3) with no distinction between deep and shallow carbonates. Similar $\mathrm{C}$ isotopic compositions $\left(\delta^{13} \mathrm{C}=\right.$ +0.07 to +2.5 ) have been reported for aragonite that precipitated from slab-derived fluids in veins of metabasalt and siltstone clasts recovered from the Conical serpentinite mud volcano (Alt and Shanks III, 2006) and for Ca carbonate chimneys that formed on the summit of Conical by mixing of upwelling fluid and seawater $\left(\delta^{13} \mathrm{C}=-3.7 \%\right.$ o to $0 \%$; Tran et al., 2014). Our $\delta^{13} \mathrm{C}$ values fall within the much wider range of $\mathrm{C}$ isotopic compositions of authigenic carbonate precipitates in serpentinite clasts and muds from several other mud volcanoes $\left(\delta^{13} \mathrm{C}=-27.4 \%\right.$ to $+10.2 \%$; Haggerty, 1987 , 1991; Gharib, 2006). 


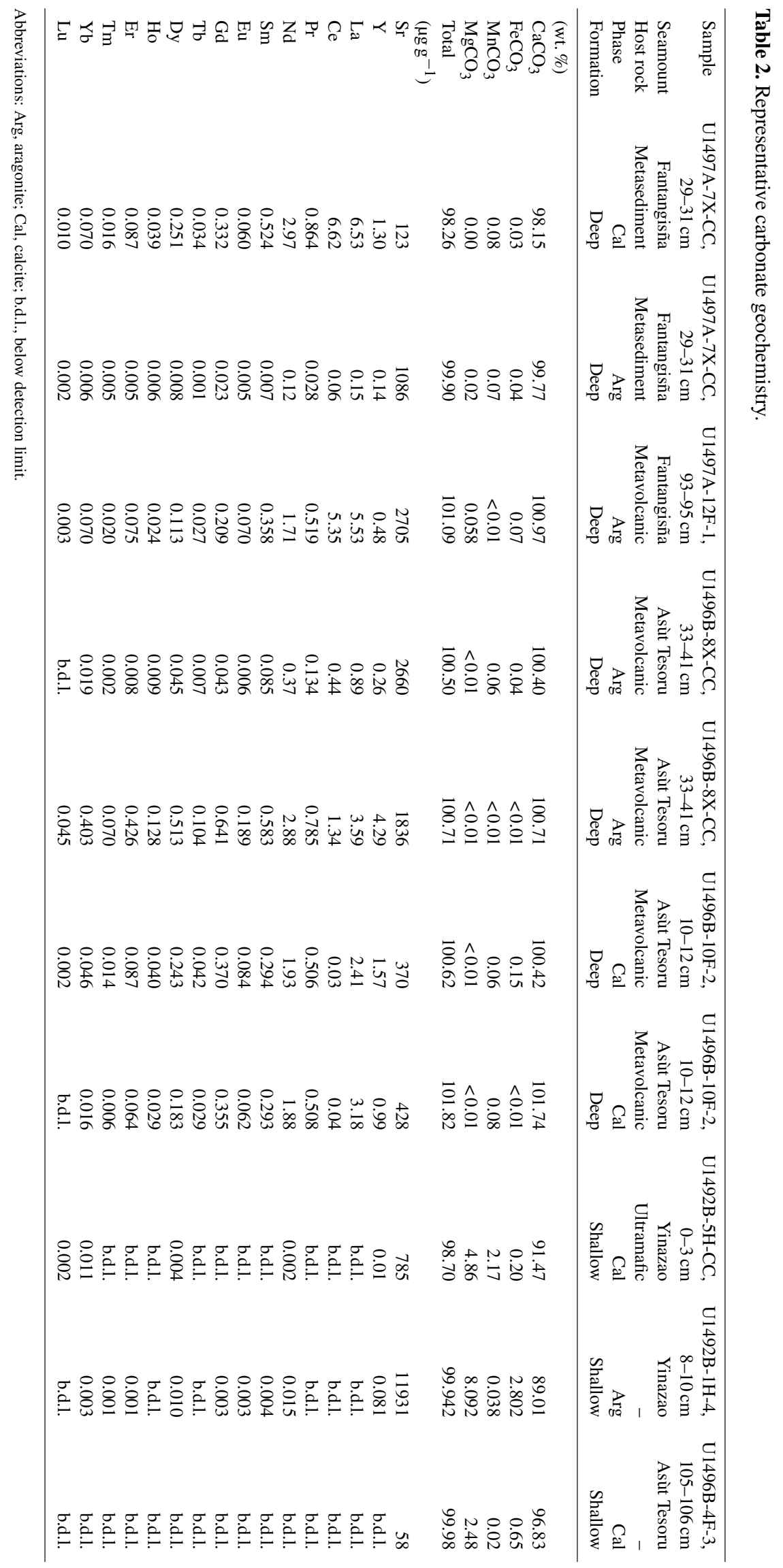


Table 3. Carbonate and sulfate $\mathrm{Sr}$ and stable isotope geochemistry.

\begin{tabular}{llrrrrr}
\hline Sample & Type & ${ }^{87} \mathrm{Sr} /{ }^{86} \mathrm{Sr}$ & $\begin{array}{r}\delta^{18} \mathrm{O} \\
(\% o)\end{array}$ & $\begin{array}{r}\delta^{13} \mathrm{C} \\
(\% o)\end{array}$ & $\begin{array}{r}\delta^{34} \mathrm{~S} \\
(\% o)\end{array}$ & $\begin{array}{r}\delta^{18} \mathrm{O}_{\mathrm{Brt}} \\
(\% \circ)\end{array}$ \\
\hline U1492B-1H-3, 16-18 cm & Authigenic & 0.70644 & 36.3 & -0.5 & - & - \\
U1492B-1H-4, 8-10 cm & Authigenic & 0.70524 & 36.2 & -0.4 & - & - \\
U1496B-4F-3, 105-106 cm & Authigenic & 0.70495 & 33.0 & 2.4 & - & - \\
U1496A-10G-CC, 23-26 cm & Metavolcanic & 0.70523 & 21.2 & 0.9 & - & - \\
U1497A-7X-CC, 29-31 cm & Metasediment & 0.70525 & 20.2 & -0.6 & 18.8 & 13.5 \\
U1498B-8R-1, 0-4cm & Metavolcanic & 0.70526 & 20.4 & 2.2 & - & - \\
U1498B-8R-1, 32-34 cm & Metavolcanic & 0.70538 & 23.5 & 3.3 & - & - \\
\hline
\end{tabular}

${ }^{13} \mathrm{C}$ in VPDB, $\delta^{18} \mathrm{O}$ in VSMOW. Abbreviations: Brt, barite; -, not detected.

Oxygen isotopic values of shallow carbonates $\left(\delta^{18} \mathrm{O}=33.0 \%{ }^{-}-36.3 \%\right.$ ) $)$ fall in the range of previously reported authigenic carbonates (Haggerty, 1987, 1991; Gharib, 2006; Tran et al., 2014), but the deep carbonates have $\delta^{18} \mathrm{O}$ values between $20.2 \%$ and $23.5 \%$, which are clearly different (Fig. 6, Table 3). These are in the range of aragonite data reported by Alt and Shanks III (2006) and are among the lowest $\delta^{18} \mathrm{O}$ values reported for carbonates from the Mariana forearc.

Barite of the carbonate-sulfate vein hosted by the quartzite sample has a $\delta^{34} \mathrm{~S}$ value of $18.8 \%$ and a $\delta^{18} \mathrm{O}$ value of $13.5 \%$ (Table 3 ).

\section{Discussion}

\subsection{Recycling of Pacific crust through serpentinite mud volcanism}

The serpentinized peridotite clasts represent forearc mantle material. In contrast, the likely origin of the metavolcanic and metasedimentary rocks is the upper oceanic crust and overlying deep marine sediments of the subducting plate. The presence of remnant Ti-rich pyroxene implies an ocean island provenance for the metavolcanic rocks (Fig. 2; Leterrier et al., 1982), in agreement with petrographic observations and geochemical data from IODP Expedition 366 and demonstrating the recycling of Pacific Plate seamount material via serpentinite mud volcanism (Fryer et al., 2018b, 2019). Secondary phases within the metavolcanic clasts illustrate a high-pressure metamorphic overprint in accordance with estimated peak pressure conditions at depth beneath Fantangisña (slab depth $\sim 14 \mathrm{~km})$ and Asùt Tesoru $(\sim 18 \mathrm{~km}$; Oakley et al., 2007, 2008; Hulme et al., 2010). Glaucophane and lawsonite, present in samples from Asùt Tesoru, indicate beginning blueschist metamorphic conditions as observed by earlier studies of similar blueschist materials from the serpentinite mud volcanoes (e.g., Maekawa et al., 1995; Fryer et al., 1999).

Quartzite breccias have not been previously described from the serpentinite mud volcanoes. We suggest that this

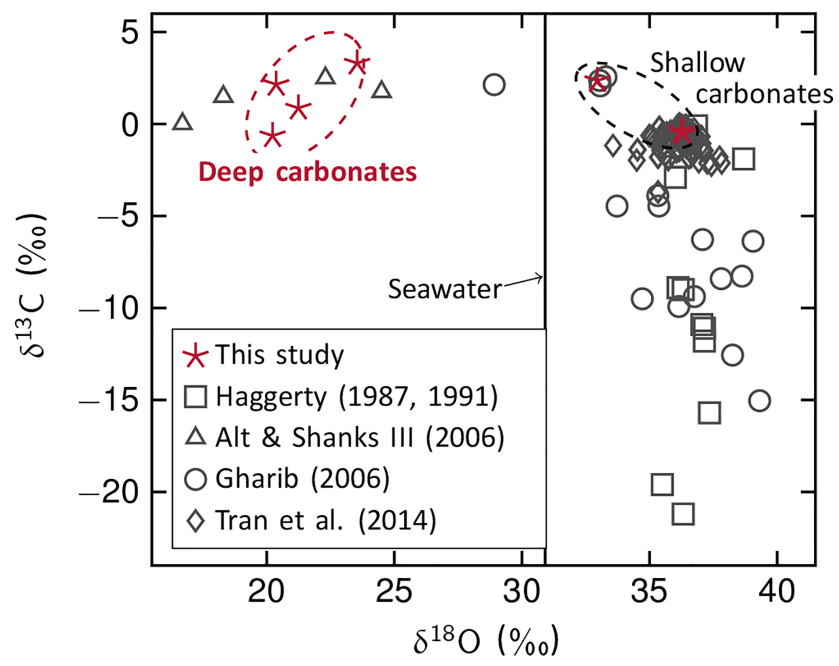

Figure 6. Carbonate $\mathrm{C}$ and $\mathrm{O}$ isotopic compositions. Carbonates from this study have slightly positive $\delta^{13} \mathrm{C}$ values, suggesting an inorganic $\mathrm{C}$ source. Oxygen isotopic values of deep carbonates are considerably lower in comparison to authigenic carbonates since they precipitated at much higher temperatures. Compositions of carbonates from other Mariana serpentinite mud volcanoes are shown for comparison, including data depicting carbonate chimneys from Conical (Tran et al., 2014), authigenic carbonates from several Mariana mud volcanoes (Haggerty, 1991; Gharib, 2006), and aragonite in metabasalt and siltstone clasts from Conical (Alt and Shanks III, 2006). The latter potentially had the same $C$ source and formed at similar high temperatures; carbonates studied by Haggerty (1991) and Gharib (2006) are influenced by organic compounds and precipitated at ambient seawater conditions.

sample represents lithified sedimentary siliceous ooze from the subducted Pacific Plate. Siliceous oozes cover large areas of the western Pacific seafloor (cf. ODP Site 801 and Site 1149; Shipboard Scientific Party, 2000), as abyssal depths in many places are below the carbonate compensation depth $(\sim$ $4.5 \mathrm{~km}$ ), leading to dissolution of the otherwise widespread calcareous plankton (e.g., Pälike et al., 2012). With progressive metamorphism during subduction, the silica-rich sediments were likely transformed into quartzite (cf. Kastner 
et al., 1981). The brecciation indicates the exposure of the quartzite to stresses at temperatures below that of the brittleplastic transition zone $\left(<300-350^{\circ} \mathrm{C}\right.$; e.g., Stipp and Kunze, 2008), which is in agreement with the estimated temperature of $150^{\circ} \mathrm{C}$ for the subduction channel below Fantangisña (Hulme et al., 2010).

\subsection{Carbonate formation in the subduction channel}

For all veins, geochemical data and textural relationships of the vein assemblages demonstrate that the precipitates formed (i) within the subduction zone and (ii) after deformation of the clasts and their eventual detachment from the forearc mantle and subducting slab, respectively. (i) The carbonate REE patterns differ substantially from those of carbonates formed during seawater circulation within mafic portions of the ocean crust where the formation of Ca carbonate veins is a common process (e.g., Alt and Teagle, 1999). Rausch (2012) studied carbonate veins within the upper oceanic crust from the west Pacific (Site 801 and Site 1149, ODP Leg 185) in host lithologies comparable to those subducted at the Izu-Bonin-Mariana convergent margin (Fig. 4). These carbonates exhibit higher REE concentrations than the carbonates in this study and enrichments in HREEs compared to our deep carbonates, which are characterized by significant depletions in HREEs and commonly with negative Ce anomalies (Fig. 4). Only one sample (U1498B-8R-1, $10-15 \mathrm{~cm}$ ) shows a slight HREE enrichment similar to Pacific crust carbonates, yet total REE concentrations are considerably lower. Hence, we rule out that the deep carbonates, namely those carbonates hosted in veins by metavolcanic and metasedimentary clasts, formed during alteration of the ocean crust before subduction. In contrast, vein carbonates in ultramafic clasts do exhibit REE concentrations and patterns similar to those of carbonates from Site 801 and Site 1149 (Fig. 4). But these veins are hosted by peridotite clasts from the forearc mantle, and hence they must have formed within the subduction zone. Further credence to the formation within the forearc is lent by the $\mathrm{Sr}$ isotopic signatures of the carbonates: their ${ }^{87} \mathrm{Sr} /{ }^{86} \mathrm{Sr}$ compositions are similar to the most unradiogenic values of the slab fluids (Fig. 5). These unradiogenic signatures represent the pore waters least influenced by mixing with seawater, and we interpret them to reflect the endmember compositions. The similar $\mathrm{Sr}$ isotopic composition of the endmember fluids and the deep carbonates imply their likely precipitation from such slab-derived fluids at depth. (ii) We further base this interpretation on textural evidence including the radial growth (e.g., Fig. 3c) and euhedral crystal shapes (e.g., Fig. 3d) of vein precipitates associated with the deep carbonates that indicate growth in stress-free environments, probably subsequent to deformation/brecciation. Their host rocks show evidence of high-pressure/low-temperature metamorphism along a cold geotherm as brittle deformation and recrystallization to pumpellyite or glaucophane. In contrast, no such indications of metamorphism were identified for the deep carbonates or associated silicates and/or barite.

We conclude that the vein assemblages including the deep carbonates have precipitated from fluids subsequent to the high-strain conditions that affected their metavolcanic and metasedimentary hosts. The veins and cavities that now host the deep carbonates can either have formed before their host rocks were detached from the slab, for instance by high pore fluid pressures resulting from ongoing fluid release (cf. Hacker et al., 2003; Taetz et al., 2018), or during breakup of the clasts within the subduction channel. During and after vein assemblage formation, relatively deviatoric stressfree environments must have prevailed to form and preserve the observed undeformed mineral textures. Nevertheless, pressure-temperature conditions during vein precipitate formation were likely similar to the peak metamorphic conditions under which their host rocks recrystallized, as indicated by the presence of aragonite and its intergrowth with lawsonite and phengite (cf. Table 1). Aragonite itself is restricted to high-pressure systems (e.g., Johannes and Puhan, 1971). Lawsonite is characteristic of metamorphic overprint of mafic rocks under blueschist facies conditions (e.g., Black, 1977) at high pressures and temperatures from 150 to $400^{\circ} \mathrm{C}$ (Essene et al., 1965; Diessel et al., 1978). Intimate intergrowth of lawsonite with aragonite (Fig. 2a) hence clearly implies that these veins formed at great depth. Furthermore, the uniform REE + Y patterns as well as Sr isotopic compositions of those deep veins suggest that they have precipitated from compositionally alike fluids with a Sr isotope signature of the invoked pore water endmember.

Temperatures of formation are difficult to constrain from metamorphic assemblages in subduction zones, but carbonate formation temperatures can be calculated from their $\delta^{18} \mathrm{O}$ values if the $\mathrm{O}$ isotopic composition of the precipitating solution is known. Pore waters of the most deeply rooted mud volcano (Asùt Tesoru) have $\delta^{18} \mathrm{O}_{\text {fluid }}$ values of $+1.7 \%$ to $+2 \%$ (Debret et al., 2019); however, it is unlikely that these fluids retained their $\mathrm{O}$ isotopic composition during their ascent from the decollement. Temperature estimates based on these isotopic compositions would range from $\sim 60$ to $95^{\circ} \mathrm{C}$ for deep carbonates (Fig. 7; O'Neil et al., 1969; Friedman and O'Neil, 1977). These values are much lower than the temperatures of 150 to $250{ }^{\circ} \mathrm{C}$ estimated for the depth of the slab interface beneath the serpentinite mud volcanoes (Hulme et al., 2010), and it seems unlikely that the $\delta^{18} \mathrm{O}$ values of the pore waters of the mud volcanoes are representative of the slab-derived fluids from which the carbonates precipitated. The precipitation of the deep carbonates presumably occurred at (considerably) higher temperatures. Alt and Shanks III (2006) calculated isotopic compositions of fluids released at depth that are in equilibrium with the weighted mean of subducting sediment (their Table 4). These authors estimated the $\delta^{18} \mathrm{O}$ value of such fluid at $12 \%$ at $200^{\circ} \mathrm{C}$ and $16 \%$ at $300{ }^{\circ} \mathrm{C}$. Adopting their approach, we calculated $\delta^{18} \mathrm{O}_{\text {fluid }}$ in equilibrium with subduct- 


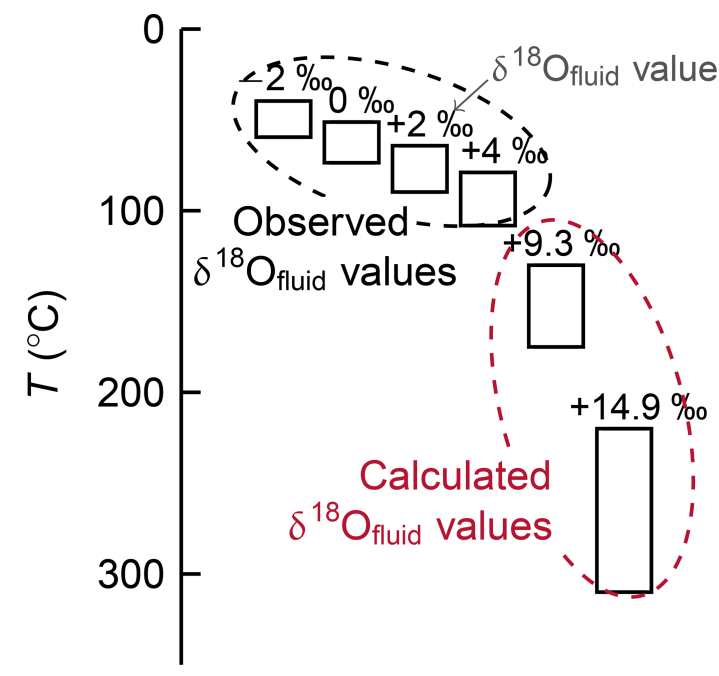

Figure 7. Estimated formation temperatures for deep carbonates. Oxygen isotopes suggest variable carbonate precipitation temperatures, depending on the isotope value of the fluid from which they formed. Pore water $\delta^{18} \mathrm{O}$ compositions increase with depth to slab from negative values at Yinazao $(-1.5 \%$ ) to positive values at Asùt Tesoru $(+2.5 \%$ ) and Conical $(+4 \% o)$. These would result in temperatures below $100{ }^{\circ} \mathrm{C}$; however, these fluids are not representative of fluid compositions at depth. In fact, calculated compositions of fluids being released from the subducting sediments have $\delta^{18} \mathrm{O}$ ranging from $9.3 \%$ to $14.9 \%$. Temperature estimates based on these values are 130 to $175^{\circ} \mathrm{C}$ and 220 to $310^{\circ} \mathrm{C}$, respectively. Serpentinite mud pore water data from Debret et al. (2019) and Mottl et al. (2004); temperature calculation following O'Neil et al. (1969) and Friedman and O'Neil (1977).

ing sediment based on fractionation coefficients for calcitewater, quartz-water, albite-water, illite-water, and chloritewater from Zheng (1993a, b, 1999). For the inferred slab temperatures of $150{ }^{\circ} \mathrm{C}$ below Fantangisña and of $250^{\circ} \mathrm{C}$ below Asùt Tesoru we obtained $\delta^{18} \mathrm{O}_{\text {fluid }}$ compositions of $9.3 \%$ o and $14.9 \%$, respectively. If the deep carbonates formed in equilibrium with these fluids, estimated precipitation temperatures are shifted to 130 to $175^{\circ} \mathrm{C}$ and to 220 to $310^{\circ} \mathrm{C}$, respectively (Fig. 7). These estimates overlap with those for carbonates hosted in metavolcanic and metasedimentary clasts from the Conical seamount that have similar O isotopic compositions $\left(\delta^{18} \mathrm{O}=16.7 \%\right.$ - $24.5 \%$; Fig. 6$)$ and are interpreted to have formed from slab-derived fluids at temperatures of up to $250^{\circ} \mathrm{C}$ (Alt and Shanks III, 2006). Fluids expelled from sediments at shallow depths in subduction zones may generally have high $\delta^{18} \mathrm{O}$ values. For instance, $\delta^{18} \mathrm{O}$ of $\sim 13 \%$ is estimated for slab-derived fluids from 25 to $45 \mathrm{~km}$ depth in the Catalina Schist subduction complex (Bebout and Barton, 1989).

However, incipient serpentinization in the subduction channel is likely to remove ${ }^{18} \mathrm{O}$ from the fluids into serpentine (e.g., Alt and Shanks III, 2006; Debret et al., 2019). Consequently, in the subduction channel, which likely contains eroded variably serpentinized materials from the basal plane of the mantle wedge, the actual $\delta^{18} \mathrm{O}_{\text {fluid }}$ may be somewhat lower. The temperatures estimated on the basis of calculated $\delta^{18} \mathrm{O}_{\text {fluid }}$ values should therefore be considered maximum estimates. But besides that, the estimated formation temperatures of 130 to $310^{\circ} \mathrm{C}$ are well in line with the presence of pectolite and prehnite associated with the deep carbonates in some of the veins. These phases require formation temperatures that well fit the above-proposed temperatures: pectolite may form at temperatures as high as 300 to $350{ }^{\circ} \mathrm{C}$ (e.g., Craw and Landis, 1980; Esteban et al., 2003), and prehnite may be stable in water-rock systems up to temperatures of $\sim 300^{\circ} \mathrm{C}$ (e.g., Bird and Spieler, 2004). Pectolite and prehnite are often associated with rodingitization (e.g., Austrheim and Prestvik, 2008), a process in which crustal rocks interacting with serpentinization fluids undergo Ca metasomatism including the formation of $\mathrm{Ca}-\mathrm{Al}$ silicates, such as hydrogarnet, prehnite, and vesuvianite (see, e.g., Bach and Klein, 2009, for details).

We suggest that the deep carbonates formed from dehydration fluids in the subduction channel close to where they were released from the downgoing slab. This idea is supported by the trace element composition of the deep carbonates, specifically the generally high concentrations of REEs and negative $\mathrm{Ce}$ anomalies. The low REE mobility and oxidizing conditions indicated by these REE compositions do not support the idea that the fluids had been modified significantly by serpentinization reactions taking place where peridotitic clasts dominate the subduction channel mélange.

Furthermore, prevailing serpentinization within the subduction channel would produce reducing conditions due to the release of $\mathrm{H}_{2}$ to the aqueous solutions (e.g., McCollom and Bach, 2009). But the pronounced negative Ce anomalies indicate that carbonate precipitation took place under fairly oxidizing conditions where Ce was tetravalent (e.g., German et al., 1991). Cerium is the only REE that can exist in the trivalent and tetravalent oxidation state; in aqueous solutions, tetravalent $\mathrm{Ce}$ is less soluble than trivalent $\mathrm{Ce}$, resulting in its precipitation and the removal of $\mathrm{Ce}$ from the fluid and the creation of the observed negative $\mathrm{Ce}$ anomalies. Cerium anomalies may hence be used as a redox proxy (e.g., German and Elderfield, 1990; Tostevin et al., 2016). We calculated the predominant redox states of $\mathrm{Ce}$ and $\mathrm{Eu}$ in the $a \mathrm{H}_{2}$ (aq) vs. temperature plane to identify the low reduction potential under which the carbonates have formed (Fig. 8; see figure caption for details on the calculations). Within the estimated temperature range of $\sim 130$ to $310^{\circ} \mathrm{C}$, tetravalent $\mathrm{Ce}$ will be stable under fairly oxidizing conditions. Since not all deep carbonates exhibit $\mathrm{Ce}$ anomalies, the conditions presumably shifted towards slightly more reducing conditions, i.e., approaching the field of trivalent Ce stability (Fig. 8). Yet, the redox conditions under which tetravalent $\mathrm{Ce}$ is expected to predominate are clearly within the stability region of $\mathrm{SO}_{4}^{2-}$ and $\mathrm{CO}_{2}$ (Fig. 8). This result is consistent with the abundance of carbonate veins and the presence of barite in 
the quartzite sample. Our estimate puts the upper boundary of $\mathrm{H}_{2}$ activity in the fluids well below levels imposed by serpentinization reactions, which would be $>\log -2$ for temperatures between 200 and $300^{\circ} \mathrm{C}$ (McCollom and Bach, 2009). Under such reducing conditions, $\mathrm{CO}_{2}$ is no longer the predominant $\mathrm{C}$ species (Fig. 8) but is instead reduced to $\mathrm{CH}_{4}$ by $\mathrm{H}_{2}$ produced during serpentinization. Calcium carbonate formation, for instance in ultramafic/serpentinite clasts, is hence less likely to occur in such conditions. These findings lend further credence to the hypothesis that the carbonate precipitation occurred in an environment that was not dominated by serpentinization reactions. It is hence likely that the deep carbonates formed within the subduction channel, where serpentinization of the mantle wedge has only a minor influence on the overall redox conditions. Instead, dehydration processes induced by prograde reactions in the subducting slab are thought to drive more oxic conditions. These processes include the release of pore waters due to sediment compaction, dehydration of opal-CT, decomposition of clay, and decarbonation (e.g., Mottl et al., 2004; Fryer et al., 2018b). On the basis of the textural relationships implying strain-free environments, we can speculate that the deep carbonate precipitation occurred after the metavolcanics/metasediments were detached from the subducting lithosphere (Fig. 9). Our isotope-based temperature estimates are in line with this interpretation as they well match inferred slab temperatures of $\sim 150^{\circ} \mathrm{C}$ beneath Fantangisña and $\sim 250^{\circ} \mathrm{C}$ beneath Asùt Tesoru.

\subsection{Processes in the mud volcano conduits}

Within the mantle wedge, serpentinization is expected to become a dominant process and the redox conditions will become reducing, as indicated by the presence of magnetite and awaruite in the serpentinite clasts (Kahl et al., 2015). These reducing conditions prevail in the mantle wedge and mud volcano conduits: Kawagucci et al. (2018) suggested that the fluids venting at the South Chamorro mud volcano had as much as $40 \mathrm{mM} \mathrm{H}_{2}$ before most of the $\mathrm{H}_{2}$ was consumed by microbial sulfate reduction. We hence suggest that there is a redox gradient across the subduction channel set up by the release of oxidized $\mathrm{CO}_{2}$ and $\mathrm{SO}_{4}^{2-}$-bearing fluids from the slab that become progressively more reducing by ongoing serpentinization reactions of wedge peridotite in the upper part of the subduction channel where peridotite dominates volumetrically over metasediment and/or oceanic crust (Fig. 9).

The veined metavolcanic clasts were exposed to these reducing conditions imposed by serpentinization reactions, but the carbonate phases preserved a record of earlier oxidizing conditions in the subduction channel. However, evidence for late-stage reactions between the metavolcanic clasts and serpentinization fluids exists in the form of vein phases such as nesquehonite, $\mathrm{Mg}\left(\mathrm{HCO}_{3}\right)(\mathrm{OH}) \cdot 2\left(\mathrm{H}_{2} \mathrm{O}\right)$, present in few clasts (cf. Table 1). This phase is stable only at tem-

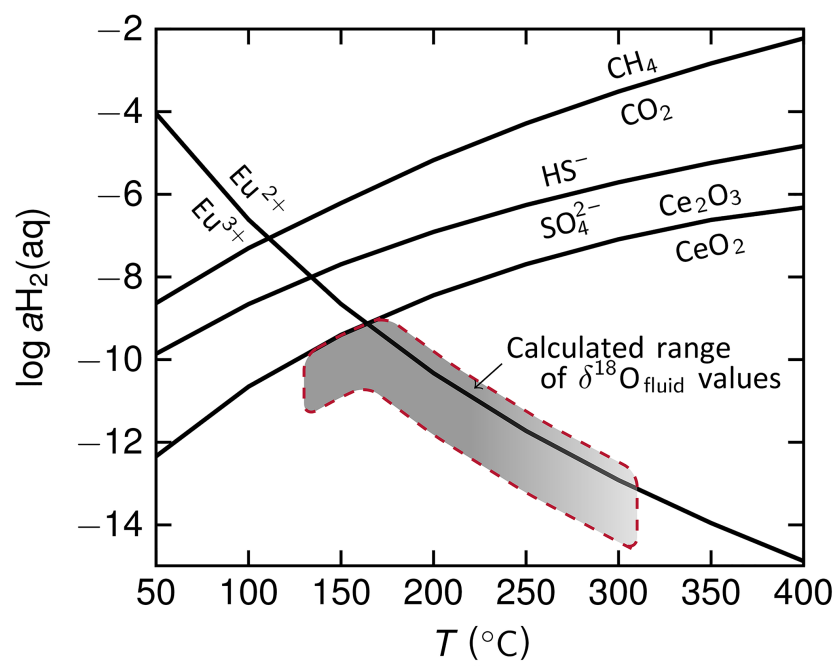

Figure 8. Predominance diagram showing the position of redox reaction equilibria for equal activities of oxidized and reduced species. Over the entire temperature range, $\mathrm{Ce}^{4+}$ is only stable under conditions of low $\log a \mathrm{H}_{2}(\mathrm{aq})$, i.e., in oxidizing environments. At these $a \mathrm{H}_{2}$ conditions, $\mathrm{CO}_{2}$ and $\mathrm{SO}_{4}^{2-}$ are stable as well. The shaded field marks the conditions under which the deep carbonate $\mathrm{Ce}$ anomalies may have developed underneath Fantangisña and Asùt Tesoru, as based on temperature estimates relying on calculated $\delta^{18} \mathrm{O}_{\text {fluid }}$ value (cf. Fig. 7). We thereby connected the individual temperature estimates beneath the two mud volcanoes since the carbonation processes in the subduction channel likely continues within this range. Europium anomalies are weakly developed (cf. Fig. 4), indicating Eu to be mostly present in a trivalent state in the fluids from which the carbonates precipitated. The positions of the reaction lines were computed with SUPCRT92 (Johnson et al., 1992) for a pressure of $50 \mathrm{MPa}$; this pressure roughly corresponds to a depth of $15 \mathrm{~km}$, which is intermediate between the inferred depths below Fantangisña and Asùt Tesoru. For the computations, thermodynamic data from Shock and Helgeson (1988), Shock et al. (1997), and Helgeson et al. (1998) for aqueous species and Robie et al. (1978) as well as Robie and Hemingway (1995) for Ce oxides were used.

peratures of $<100^{\circ} \mathrm{C}$ (Davies and Bubela, 1973; Suzuki and Ito, 1974; Ballirano et al., 2010) and forms exclusively in alkaline environments (Wilson et al., 2009). Thaumasite, $\mathrm{Ca}_{3} \mathrm{Si}\left(\mathrm{CO}_{3}\right)\left(\mathrm{SO}_{4}\right)(\mathrm{OH})_{6} \cdot 12\left(\mathrm{H}_{2} \mathrm{O}\right)$, another lowtemperature alteration phase in mafic rocks, forms preferentially in the presence of carbonate and sulfate at low temperatures and under alkaline conditions (e.g., Karpoff et al., 1992; Schmidt et al., 2008). Within the marine realm, the formation of thaumasite occurs at temperatures of $<100^{\circ} \mathrm{C}$ (e.g., Noack, 1983; Karpoff et al., 1992). Nesquehonite and thaumasite are not directly intergrown with the deep carbonates but rather occur in veins that in some cases crosscut the deep carbonates. They likely formed during low-temperature alteration of the clasts below or within the mud volcanoes.

The precipitation of shallow carbonates within the mud volcanoes took place under conditions drastically different 
from the deep carbonate formation, as indicated by their contrasting $\mathrm{O}$ isotope compositions (Fig. 6, Table 3). Radiating clusters of aragonite at Yinazao have exceptionally high $\delta^{18} \mathrm{O}$ values $(\sim 36.6 \%$ o), which leads to unrealistically low calculated formation temperatures (following Grossman and $\mathrm{Ku}, 1986)$ if the lowest $\delta^{18} \mathrm{O}_{\text {fluid }}$ value $(-1.5 \%$; Debret et al., 2019) is assumed. Temperatures calculated for the highest values of $\delta^{18} \mathrm{O}_{\text {fluid }}$ at Yinazao $(+0.6 \%$ ) would be just below $1{ }^{\circ} \mathrm{C}$. Temperatures of 3.0 and $15.6^{\circ} \mathrm{C}$ are computed for the calcite crystal $\left(\delta^{18} \mathrm{O}=33 \%\right.$ ) recovered from Asùt Tesoru (using Friedmann and O'Neil, 1977) and the range of $\delta^{18} \mathrm{O}_{\text {fluid }}$ values of pore water $(-0.2 \%$ o to $+2.5 \%$; Debret et al., 2019). These estimates imply a formation of the shallow carbonates at low temperatures, which is in accordance with results of earlier work (Gharib, 2006; Tran et al., 2014).

The very low REE $+\mathrm{Y}$ contents of authigenic aragonite and calcite and of carbonate hosted in veins of the serpentinite clasts and one metavolcanic clast may point to a fluid source distinct from the slab-derived fluids. Low total $\mathrm{REE}+\mathrm{Y}$ concentrations would be plausible if seawater was mixed in the shallow muds of the serpentinite mud volcanoes (REE concentrations in NW Pacific bottom water are <60 pM; e.g., Piepgras and Jacobsen, 1992). The cooccurrence of iowaite with the shallow carbonates implies oxic conditions, further strengthening our conclusion of the presence of seawater (cf. Heling and Schwarz, 1992; Bach et al., 2004). Seawater would as well provide $\mathrm{Cl}^{-}$during the formation of iowaite. Yet, this interpretation is inconsistent with the similar ${ }^{87} \mathrm{Sr} /{ }^{86} \mathrm{Sr}$ isotopic compositions of the deep and shallow carbonates, indicating that entrainment of seawater in the shallow parts of the system was minimal (no apparent seawater fraction for two out of three authigenic carbonate samples; cf. Fig. 6). The lower REE + Y contents of the shallow carbonates may hence be more plausibly explained by (i) a loss of the REEs en route to the surface (cf. Kahl et al., 2015; see also next section) or (ii) lower precipitation temperatures that will favor crystal-chemical discrimination against REEs.

If the pore waters from the mud volcanoes indeed represent cooled slab-derived fluids, then the oxygen isotopic composition must have been considerably changed from high initial $\delta^{18} \mathrm{O}$ values to overall seawater-like compositions near the seafloor. This shift in $\delta^{18} \mathrm{O}$ may be caused by isotopic exchange in the mud between water and serpentine, which has higher $\delta^{18} \mathrm{O}$ values than mantle wedge peridotites (e.g., Alt and Shanks III, 2006; Debret et al., 2019) and may hence explain the postulated decrease in $\delta^{18} \mathrm{O}$ values in the interacting fluids. The magnitude of the shift would indicate very low water-to-rock ratios.

\subsection{Element transfers into the mantle wedge}

\subsubsection{Fluid release and subsequent fluid-mineral interactions}

In addition to help constraining the temperature and redox conditions in the mud volcanoes' plumbing system, our results yield insights into the transport of elements from slab to seafloor. Barite intergrown with aragonite represents sulfate that was subducted with the downgoing slab. Sediment pore waters of the subducting lithosphere contain seawater with distinct sulfate concentrations (D'Hondt et al., 2002). The isotopic composition of barite $\left(\delta^{34} \mathrm{~S}=18.8 \%\right.$ ) is lower than that of modern seawater $(21 \%$ ). In the Cretaceous and Cenozoic ocean water, $\delta^{34} \mathrm{~S}$ values of sulfate were as low as $\sim 15 \%$ o (e.g., Paytan et al., 2014). Since the downgoing plate is inferred to have an age of $>150 \mathrm{Ma}$ (Müller et al., 2008), the isotopic composition of barite may record the signature of Upper Mesozoic or Cenozoic seawater.

Strontium isotopic compositions and high LREE + Y contents of the deep carbonates provide additional evidence for mass transfer from the slab to the subduction channel and hanging wall. The unradiogenic values of ${ }^{87} \mathrm{Sr} /{ }^{86} \mathrm{Sr}$ ranging from 0.70495 to 0.70566 cannot be reconciled with simple expulsion of seawater trapped in void space of the subducting sediment and basement. A fraction of the Sr must have also been released from slab minerals in the course of dehydration to explain the low ${ }^{87} \mathrm{Sr} /{ }^{86} \mathrm{Sr}$ of the veins. Textural relations between the deep carbonates and silicates as well as barite imply that these phases grew simultaneously. The associations of carbonate with silicates or barite can be observed in the clasts of the intermediate-sourced Fantangisña and deep-sourced Asùt Tesoru, indicating an input of slabderived dissolved inorganic carbon (DIC) in slab-interface depths of $>14 \mathrm{~km}$. For these mud volcanoes, the element release by dehydration of subducted clays and altered basalt has been suggested based on pore water compositions (Mottl et al., 2004; Hulme et al., 2010). These authors further proposed from an across-forearc comparison of pore water compositions that compositional differences are due to progressive slab dewatering and related element release (e.g., Mottl et al., 2004; Hulme et al., 2010; Fryer et al., 2018b). The $\mathrm{Ca}$ and $\mathrm{Sr}$ contents of the pore waters do reflect the distribution of vein carbonates in the clasts, indicating that deep slab-derived fluids are preserved in the mud volcano fluids all the way from the top of the subducting slab to the seafloor. This seems particularly true for $\mathrm{Sr}$ isotopic compositions. It is, however, likely that the contents of elements less mobile than $\mathrm{Ca}$ and $\mathrm{Sr}$ are influenced by fluid-rock interactions. Geochemical studies of veined clasts show that these interactions do take place. Slab-derived fluid compositions are altered by interactions of these fluids by subsequent exchange processes with rocks in the subduction channel and forearc. Using trace element compositions of serpentine veins from South Chamorro, Kahl et al. (2015) showed that trace ele- 


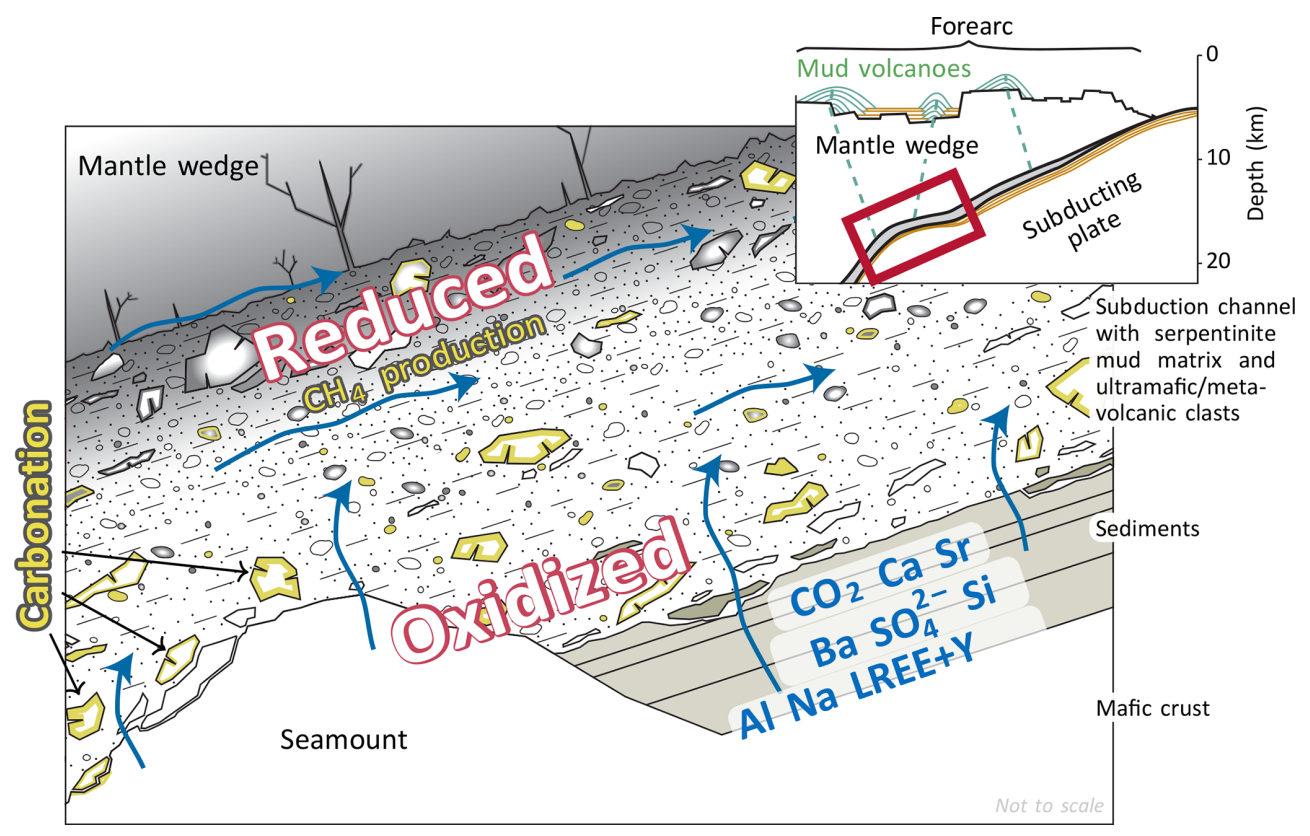

Figure 9. Cartoon illustrating inferred conditions within the subduction channel below the Mariana forearc. Dehydration and decarbonation reactions release $\mathrm{CO}_{2}, \mathrm{SO}_{4}^{2-}$, and other elements into the subduction channel, where carbonation of metavolcanic clasts occurs in veins and, potentially, along their margins under oxidizing conditions. Towards the mantle wedge, conditions become increasingly reducing. Here, $\mathrm{CO}_{2}$ contents are likely lower due to (1) prior removal by carbonate formation and (2) partial reduction to $\mathrm{CH}_{4}$ by $\mathrm{H}_{2}$ produced during serpentinization. See text for further discussion. Inset modified from Fryer et al. (2018b).

ment and Si concentrations were high during early but low during later serpentinization stages of ultramafic clasts. This trend was interpreted to result from an en route loss of these elements from the fluids to the rocks within the subduction channel and/or mud volcano conduit. Our results show that the highly immobile behavior of REEs (e.g., Hermann et al., 2006) likely resulted in rapid uptake by early precipitates. The depletion from the ascending fluids then gave rise to low concentrations of REEs in the shallow carbonates of the serpentinite mud volcanoes. Other species that were incorporated into the vein assemblages, such as $\mathrm{Al}$ in lawsonite, were likely sequestered from the slab-derived fluids in a similar manner.

Calcium-rich vein phases, namely aragonite, calcite, pectolite, prehnite, and lawsonite, derive their $\mathrm{Ca}$ either from slab-derived fluids or it is provided by the Ca-rich metavolcanic host rocks (mid-ocean ridge and ocean island basalt in the Pacific Ocean basin typically contain $>8 \mathrm{wt} \% \mathrm{CaO}$; e.g., Dasgupta et al., 2010; White and Klein, 2014). The latter could be particularly important at Asùt Tesoru, where $\mathrm{Ca}$ (and $\mathrm{Sr}$ ) concentrations in the shallow pore waters and seep fluids are low (Mottl et al., 2004; Fryer et al., 2018b). If these low $\mathrm{Ca}$ and $\mathrm{Sr}$ concentrations were inherited from processes in the subduction channel, it would support the formation of deep carbonate veins in basalt clasts and the quartzite breccia sample of Asùt Tesoru. In contrast, the very high concentrations of $\mathrm{Ca}(58 \mathrm{mM}$ on average; Wheat et al., 2018) and $\mathrm{Sr}$ (mostly $>600 \mu \mathrm{M}$ ) in shallow fluids at Yinazao may indicate a lack of carbonate precipitation at depth. This idea is consistent with a lack of carbonate veins in the clasts at Yinazao. Calcium and $\mathrm{Sr}$ concentrations in pore waters at Fantangisña are intermediate, as is to be expected based on slab depths and inferred slab interface temperatures that are in between those at Asùt Tesoru and Yinazao. The deep carbonate distribution hence appears to support published models (Mottl et al., 2004; Hulme et al., 2010) that interpret the geochemical diversity of fluids seeping at the seafloor as reflecting differences in the compositions of the fluids liberated from the downgoing slab at different depths and temperatures as well as post-liberation fluid-rock interactions.

\subsubsection{Element sources}

The constituents needed to precipitate the vein carbonates as well as coexisting minerals may have been provided by the slab-derived fluids (external source) or were present in the respective clasts that reacted with the fluids (internal source). This is particularly true for $\mathrm{C}, \mathrm{Na}, \mathrm{Al}, \mathrm{Si}, \mathrm{SO}_{4}^{2-}, \mathrm{Ca}, \mathrm{Sr}$, and $\mathrm{Ba}$ as well as REEs. Comparison of $\mathrm{Sr}$ isotope compositions of the deep carbonates with that of upwelling fluids attests to a formation from slab-derived fluids. We argue that this is indicative of a fluid-dominated system, i.e., high water/rock ratios, and hence of external sources for the chemical species stated above. Nevertheless, more rock-dominated interactions between fluids and clasts may have prevailed in narrow, sub-millimeter-wide veinlets crosscutting the metavol- 
canic samples; internal element sources cannot be ruled out in these cases.

The elements are likely liberated during the breakdown of opal and clay in subducted sediments and crust and/or during reactive fluid flow through slab- and subduction channel materials (e.g., John et al., 2008). The similarity in REE + Y patterns of sediments and deep carbonates (Fig. 4) is suggestive of a sediment source, but these patterns may be biased by the presence of other vein phases. For instance, lawsonite serves as a primary host for REEs under blueschist facies conditions (Spandler et al., 2003); the REE patterns of aragonite intergrown with lawsonite in metavolcanic sample U1496B-8X-CC, 33-41 cm, are consequently a function of the REE incorporation into lawsonite and may not represent the composition of the fluid initially released from the slab. Other vein phases coexisting with the deep carbonates may have similar effects so that we cannot make a conclusive statement on the primary element sources. However, C isotopic compositions ( $\delta^{13} \mathrm{C}=-0.6 \%$ o to $+3.3 \%$ ) imply the $\mathrm{C}$ to be derived from inorganic portions of the subducted sediments or volcanic ocean crust (e.g., Craig, 1953).

It has been proposed that the compositions of venting fluids across the Mariana forearc sequentially change in response to pressure and temperature conditions within the subduction channel, reflecting progressive devolatilization processes that trigger fluid and elemental release from the downgoing slab (e.g., Mottl et al., 2004; Hulme et al., 2010; Fryer et al., 2018b). However, it is likely that fluid compositions at depth differ from what has been measured in seafloor samples. Initial fluid compositions are altered by mineral dissolution and precipitation during metamorphic and metasomatic exchanges occurring in the forearc (e.g., Kahl et al., 2015). Low elemental concentrations in pore waters in the serpentinite mud volcanoes may hence either indicate that no significant amounts of the respective species to have been released from the slab or that these were exhausted during fluid-rock interactions and mineral precipitation during fluid transit to the seafloor.

\subsection{Implications for carbon cycling}

Our data provide important insights into understanding the transfer of carbonic fluids from the subducting slab and reactions of these fluids with rocks in the subduction channel. The data show that $\mathrm{C}$ is mobilized from the downgoing slab at subduction depths as shallow as $\sim 14 \mathrm{~km}$ and lower blueschist facies temperatures within the Mariana subduction system $\left(\sim 150^{\circ} \mathrm{C}\right)$. The mobilization of $\mathrm{C}$ at these low metamorphic grades is in accordance with experimental evidence (Caciagli and Manning, 2003) that shows that calcite solubility increases with pressure and temperature at pressures $\geq 0.3 \mathrm{GPa}$. Some of the $\mathrm{C}$ mobilized subsequently rises through the forearc with upwelling fluids and is either incorporated into carbonate precipitates within the serpentinite mud volcanoes or reduced to methane and transported back to the seafloor by serpentinite mud volcano activity (Mottl et al., 2004; Hulme et al., 2010; Fryer et al., 2018b). Associated with the redox gradient within the subduction channel from oxidizing conditions at the slab interface to more reducing conditions at the interface with the mantle wedge, a change in the $\mathrm{C}$ oxidation state from carbonate to methane is likely. In the model we propose (Fig. 9), metavolcanic and metasediment clasts react with slab-derived carbonic fluids and form carbonates in fractures and voids. DIC contents are likely lowered by (1) removal in $\mathrm{CaCO}_{3}$ veins and (2) partial reduction to $\mathrm{CH}_{4}$ by $\mathrm{H}_{2}$ produced during serpentinization. Both mechanisms would help explain why deep carbonate veins were not observed in serpentinite clasts.

The abundance of carbonate veins in clasts from mud volcanoes with slab depths of $\geq 14 \mathrm{~km}$ shows that a large portion of $\mathrm{C}$ may be trapped by carbonate mineralization within the subduction channel. The REE $+\mathrm{Y}$ characteristics of these carbonates indicate that the redox conditions within the subduction channel are oxic and within the stability field of DIC (and not methane). Carbon isotope compositions $\left(\delta^{13} \mathrm{C}=-0.6 \%\right.$ o to $+3.3 \%$ o $)$ also show that $\mathrm{CO}_{2}$ reduction, which would deplete ${ }^{12} \mathrm{C}$ from the DIC pool, has not occurred. Carbonate veins in clasts of metasediment were also recovered from Conical ( $\sim 19 \mathrm{~km}$ depth to slab; Shipboard Science Party, 1990); these carbonate minerals have C isotopic compositions $\left({ }^{13} \mathrm{C}=+0.07 \%\right.$ to $+2.5 \%$; Alt and Shanks III, 2006) similar to the carbonates studied here. The presence of these carbonates shows that the mobilization of $\mathrm{C}$ continues to greater depths. The bulk of these carbonates presumably is not entrained into the serpentinite mud volcano conduits and may remain in the forearc mantle or be subducted deeper.

Based on the pore water compositions of the Mariana serpentinite mud volcanoes, it has previously been suggested that the decarbonation of the subducted slab initiates at depths of $<30$ km (e.g., Mottl et al., 2004; Hulme et al., 2010; Fryer et al., 2018b). Our examination of the deep carbonate precipitates formed within the subduction channel provides information on geochemical conditions at depths of $\sim 14$ to $18 \mathrm{~km}$ and potential C sources. Samples from these shallow slab depths have not previously been described, and hence shallow decarbonation processes have not been assessed. Geochemical modeling, experiments, and field evidence have focused on potential $\mathrm{C}$ mobilization at greater depths and temperatures of $>300{ }^{\circ} \mathrm{C}$ (e.g., Molina and Poli, 2000; Kerrick and Connolly, 2001; Newton and Manning, 2002; Dasgupta et al., 2004; Gorman et al., 2006; Frezzotti et al., 2011; Ague and Nicolescu, 2014; Sverjensky et al., 2014; Piccoli et al., 2016; Schwarzenbach et al., 2018; Sieber et al., 2018). Budgets for the deep carbon cycle are hence plagued by very large uncertainties (e.g., Dasgupta and Hierschmann, 2010; Füri et al., 2010; Kelemen and Manning, 2015).

Reservoirs of $\mathrm{C}$ as well as its mobilization and fluxes in shallow regions of subduction zones are important components of Earth's carbon cycle. Our data are in line with the 
suggestion that simple devolatilization reactions do not account for the mobilization of $\mathrm{C}$ within these shallow portions of the subduction system (e.g., Kerrick and Connolly, 2001). Instead, we suggest that fluid-induced dissolution of carbonate (e.g., Poli et al., 2009) is the more likely process that leads to the release of $\mathrm{C}$ under shallow forearc conditions. Kelemen and Manning (2015) estimated the global C flux into the leading edge of the mantle wedge to $>1 \mathrm{Mt} \mathrm{a}^{-1}$. This budget includes $\mathrm{C}$ loss due to venting of carbonic fluids as it occurs in the Mariana forearc but does not cover the solid storage of $\mathrm{C}$ within the shallow portions of subduction systems. Such solid storage may sequester large amounts of the C released from the slab (e.g., $>90 \%$ in the Costa Rican forearc; Barry et al., 2019). Our study highlights that additional work is needed to better understand the shallow processes that affect the cycling of $\mathrm{C}$.

\section{Conclusions}

Clasts recovered from serpentinite mud volcanoes at the Mariana forearc provide insights into shallow subduction zone processes. The clasts include serpentinite, metavolcanic, and metasedimentary rock types with carbonate \pm silicate \pm sulfate veins. The samples can be subdivided into two groups.

1. Veins comprising deep carbonates are present in metavolcanic and metasedimentary clasts from the subducting Pacific Plate. Phase assemblages, euhedral textures, and geochemical data suggest that these veins formed within the subduction channel after the clasts were detached from subducted lithosphere. Negative Ce anomalies in carbonate and the co-occurrence of sulfate imply precipitation under oxic conditions, and carbonate $\mathrm{O}$ isotopic compositions imply temperatures of $\sim 130$ to $300{ }^{\circ} \mathrm{C}$. This interpretation is consistent with rock-dominated carbonate ${ }^{87} \mathrm{Sr} /{ }^{86} \mathrm{Sr}$ isotopic compositions that indicate considerable exchange of Sr between seawater-derived fluids and igneous rocks within the slab and subduction channel. Mass transfers from the subducting Pacific slab to the subduction channel are particularly apparent for $\mathrm{C}, \mathrm{Sr}, \mathrm{SO}_{4}^{2-}, \mathrm{Ba}$, and LREEs; $\mathrm{C}$ is inorganic and is likely derived from the decarbonation of carbonaceous sediment and/or oceanic crust.

2. Shallow carbonates are mainly hosted in veins of variably serpentinized ultramafic clasts originating from the forearc mantle of the Philippine Sea Plate. Crosscutting relationships imply a late formation of these veins, and coexisting iowaite points at precipitation from oxidizing, Cl-containing fluids. The carbonate REE + Y patterns are similar to those of acicular, authigenic aragonite and calcite that formed at ambient seawater temperatures within the serpentinite mudflows. Carbon in- corporated in these carbonates is inorganic; it may be slab-derived or sourced from seawater.

Our data indicate that $\mathrm{C}$ is mobilized from the downgoing slab at subduction depths of $<20 \mathrm{~km}$ and low metamorphic grades (lower blueschist facies temperatures or below) within the Mariana subduction system. Some of the mobilized $\mathrm{C}$ rises through the forearc with upwelling fluids and contributes to the formation of (shallow) carbonate precipitates within the serpentinite mud volcanoes or is reduced to methane and transported back to the short-term carbon cycle by fluids that vent at the seafloor. However, another fraction of the mobilized $\mathrm{C}$ is trapped during (deep) carbonate mineralization under oxic conditions within the subduction channel. Some of these veins are brought to the seafloor by mud volcanism, but presumably a larger fraction of these carbonates may remain at depth or may continue to be subducted to deeper levels.

Data availability. Data used in this study are available at PANGAEA $^{\circledR}$ (https://doi.pangaea.de/10.1594/PANGAEA.902648; Albers et al., 2019).

Supplement. The supplement related to this article is available online at: https://doi.org/10.5194/se-10-907-2019-supplement.

Author contributions. EA carried out sampling, analyses, and data evaluation, except for pore fluids (CDM) and carbonate Sr isotopes (FL). FK supervised the Raman work. WB conducted the thermodynamic calculations and helped with interpretation. EA prepared the manuscript with contributions from all co-authors. EA, WB, and CDM acquired funding for this project.

Competing interests. The authors declare that they have no conflict of interest.

Special issue statement. This article is part of the special issue "Exploring new frontiers in fluid processes in subduction zones". It is a result of the EGU Galileo conference "Exploring new frontiers in fluid processes in subduction zones", Leibnitz, Austria, 2429 June 2018.

Acknowledgements. We thank the conveners and participants of the EGU Galileo conference "Exploring new frontiers in fluid processes in subduction zones" for inspiring discussions and for inviting this contribution. We are grateful to the captain and crew of the D/V JOIDES Resolution, to the Expedition 366 co-chief scientists Patricia Fryer and Geoffrey Wheat, and to the members of the Science Party. Timm John is thanked for stimulating discussions and comments on an earlier version of this contribution. Harald Strauß and Henning Kuhnert are thanked for the analyses of sulfate $\mathrm{O}$ and $\mathrm{S}$ (HS) as well as carbonate $\mathrm{C}$ and $\mathrm{O}$ isotopes (HK) and 
Patrick Monien for help with LA-ICP-MS analyses. Constructive comments and reviews by Melanie Sieber and an anonymous reviewer helped to improve this paper. This research used samples and data provided by IODP.

Financial support. Funding was provided by the Deutsche Forschungsgemeinschaft (grant no. BA1605/18-1) and the Natural Environment Research Council (grant no. NE/P020909/1). Elmar Albers received financial support from the BremenIDEA out-program and from GLOMAR - Bremen International Graduate School for Marine Sciences.

The article processing charges for this open-access publication were covered by the University of Bremen.

Review statement. This paper was edited by Simone Tumiati and reviewed by Melanie Sieber and one anonymous referee.

\section{References}

Ague, J. J. and Nicolescu, S.: Carbon dioxide released from subduction zones by fluid-mediated reactions, Nat. Geosci., 7, 355, https://doi.org/10.1038/ngeo2143, 2014.

Albers, E., Bach, W., Klein, F., Menzies, C. D., Lucassen, F., and Teagle, D. A. H.: Geochmistry and isotopic compositions of metavolcanic and metasedimentary rock-hosted minerals and serpentinite mud pore waters, recovered at the Mariana forearc during IODP Exp366, dataset, PANGAEA, https://doi.pangaea. de/10.1594/PANGAEA.902648, 2019.

Alt, J. and Shanks III, W.: Stable isotope compositions of serpentinite seamounts in the Mariana forearc: serpentinization processes, fluid sources and sulfur metasomatism, Earth Planet. Sc. Lett., 242, https://doi.org/10.1016/j.epsl.2005.11.063, 272-285, 2006.

Alt, J. C. and Teagle, D. A. H.: The uptake of carbon during alteration of ocean crust, Geochim. Cosmochim. Acta, 63, 15271535, https://doi.org/10.1016/s0016-7037(99)00123-4, 1999.

Austrheim, H. and Prestvik, T.: Rodingitization and hydration of the oceanic lithosphere as developed in the Leka ophiolite, north-central Norway, Lithos, 104, 177-198, https://doi.org/10.1016/j.lithos.2007.12.006, 2008.

Bach, W. and Klein, F.: The petrology of seafloor rodingites: insights from geochemical reaction path modeling, Lithos, 112, 103-117, https://doi.org/10.1016/j.lithos.2008.10.022, 2009.

Bach, W., Garrido, C. J., Paulick, H., Harvey, J., and Rosner, M.: Seawater-peridotite interactions: first insights from ODP Leg 209, MAR $15^{\circ} \mathrm{N}$, Geochem. Geophys. Geosyst., 5, Q09F26Q09F26, https://doi.org/10.1029/2004gc000744, 2004.

Bach, W., Rosner, M., Jöns, N., Rausch, S., Robinson, L. F., Paulick, H., and Erzinger, J.: Carbonate veins trace seawater circulation during exhumation and uplift of mantle rock: results from ODP Leg 209, Earth Planet. Sc. Lett., 311, 242-252, https://doi.org/10.1016/j.epsl.2011.09.021, 2011.

Ballirano, P., De Vito, C., Ferrini, V., and Mignardi, S.: The thermal behaviour and structural stability of nesquehonite, $\mathrm{MgCO}_{3} \cdot 3 \mathrm{H}_{2} \mathrm{O}$, evaluated by in situ laboratory parallel-beam
X-ray powder diffraction: new constraints on $\mathrm{CO}_{2}$ sequestration within minerals, J. Hazard. Mater., 178, 522-528, https://doi.org/10.1016/j.jhazmat.2010.01.113, 2010.

Barry, P. H., de Moor, J. M., Giovannelli, D., Schrenk, M., Hummer, D. R., Lopez, T., Pratt, C. A., Alpízar Segura, Y., Battaglia, A., Beaudry, P., Bini, G., Cascante, M., d'Errico, G., di Carlo, M., Fattorini, D., Fullerton, K., Gazel, E., Gonzáles, G., Halldóorsson, S. A., Iacovino, K., Kulongoski, J. T., Manini, E., Martínez, M., Miller, H., Nakagawa, M., Ono, S., Patwardhan, S., Ramírez, C. J., Regoli, F., Smedile, F., Turner, S., Vetriani, C., Yücel, M., Ballentine, C. J., Fischer, T. P., Hilton, D. R., and Lloyd, K. G.: Forearc carbon sink reduces long-term volatile recycling into the mantle, Nature, 568, 487-492, https://doi.org/10.1038/s41586019-1131-5, 2019.

Bebout, G. E. and Barton, M. D.: Fluid flow and metasomatism in a subduction zone hydrothermal system: Catalina Schist terrane, California, Geology, 17, 976-980, https://doi.org/10.1130/00917613(1989)017<0976:ffamia>2.3.co;2, 1989.

Bird, D. K. and Spieler, A. R.: Epidote in geothermal systems, Rev. Miner. Geochem., 56, 235-300, https://doi.org/10.2138/gsrmg.56.1.235, 2004.

Black, P. M.: Regional high-pressure metamorphism in new caledonia: phase equilibria in the ouégoa district, Tectonophysics, 43 , 89-107, https://doi.org/10.1016/0040-1951(77)90007-5, 1977.

Blundy, J., Cashman, K. V, Rust, A., and Witham, F.: A case for $\mathrm{CO}_{2}$-rich arc magmas, Earth Planet. Sc. Lett., 290, 289-301, https://doi.org/10.1016/j.epsl.2009.12.013, 2010.

Caciagli, N. C. and Manning, C. R.: The solubility of calcite in water at 6-16 kbar and 500-800 C, Contrib. Miner. Pet., 146, 275285, https://doi.org/10.1007/s00410-003-0501-y, 2003.

Cook-Kollars, J., Bebout, G. E., Collins, N. C., Angiboust, S., and Agard, P.: Subduction zone metamorphic pathway for deep carbon cycling: I. Evidence from HP/UHP metasedimentary rocks, Italian Alps, Chem. Geol., 386, 31-48, https://doi.org/10.1016/j.chemgeo.2014.07.013, 2014.

Craig, H.: The geochemistry of the stable carbon isotopes, Geochim. Cosmochim. Acta, 3, 53-92, https://doi.org/10.1016/0016-7037(53)90001-5, 1953.

Craw, D. and Landis, C. A.: Authigenic pectolite, stevensite, and pyroaurite in a Quaternary debris flow, Southland, New Zealand, J. Sediment. Res., 50, 497-503, https://doi.org/10.1306/212f7a3b2b24-11d7-8648000102c1865d, 1980.

Dasgupta, R. and Hirschmann, M. M.: The deep carbon cycle and melting in Earth's interior, Earth Planet. Sc. Lett., 298, 1-13, https://doi.org/10.1016/j.eps1.2010.06.039, 2010.

Dasgupta, R., Hirschmann, M. M., and Withers, A. C.: Deep global cycling of carbon constrained by the solidus of anhydrous, carbonated eclogite under upper mantle conditions, Earth Planet Sc. Lett., 227, 73-85, https://doi.org/10.1016/j.eps1.2004.08.004, 2004.

Dasgupta, R., Jackson, M. G., and Lee, C.-T. A.: Major element chemistry of ocean island basalts - conditions of mantle melting and heterogeneity of mantle source, Earth Planet. Sc. Lett., 289, 377-392, https://doi.org/10.1016/j.eps1.2009.11.027, 2010.

Davies, P. J. and Bubela, B.: The transformation of nesquehonite into hydromagnesite, Chem. Geol., 12, 289-300, https://doi.org/10.1016/0009-2541(73)90006-5, 1973.

Debret, B., Albers, E., Walter, B., Price, R., Barnes, J. D., Beunon, H., Facq, S., Gillikin, D. P., Mattielli, N., and Williams, 
H.: Shallow forearc mantle dynamics and geochemistry: new insights from IODP Expedition 366, Lithos, 326-327, 230-245, https://doi.org/10.1016/j.lithos.2018.10.038, 2019.

Deniel, C. and Pin, C.: Single-stage method for the simultaneous isolation of lead and strontium from silicate samples for isotopic measurements, Anal. Chim. Acta, 426, 95-103, https://doi.org/10.1016/s0003-2670(00)01185-5, 2001.

D'Hondt, S., Rutherford, S., and Spivack, A. J.: Metabolic activity of subsurface life in deep-sea sediments, Science, 295, 20672070, https://doi.org/10.1126/science.1064878, 2002.

Diessel, C. F. K., Brothers, R. N., and Black, P. M.: Coalification and graphitization in high-pressure schists in New Caledonia, Contrib. Miner. Pet., 68, 63-78, https://doi.org/10.1007/bf00375447, 1978.

Essene, E. J., Fyfe, W. S., and Turner, F. J.: Petrogenesis of Franciscan glaucophane schists and associated metamorphic rocks, California, Beitr. Miner. Pet., 11, 695-704, https://doi.org/10.1007/bf01128709, 1965.

Esteban, J. J., Cuevas, J., Tubía, J. M., and Yusta, I.: Xonotlite in rodingite assemblages from the Ronda peridotites, Betic Cordilleras, Southern Spain, Can. Miner., 41, 161-170, https://doi.org/10.2113/gscanmin.41.1.161, 2003.

Falk, E. S. and Kelemen, P. B.: Geochemistry and petrology of listvenite in the Samail ophiolite, Sultanate of Oman: complete carbonation of peridotite during ophiolite emplacement, Geochim. Cosmochim. Acta, 160, 70-90, https://doi.org/10.1016/j.gca.2015.03.014, 2015.

Frezzotti, M. L., Selverstone, J., Sharp, Z. D., and Compagnoni, R.: Carbonate dissolution during subduction revealed by diamond-bearing rocks from the Alps, Nat. Geosci., 4, 703, https://doi.org/10.1038/ngeo1246, 2011.

Friedman, I. and O'Neil, J. R.: Compilation of stable isotope fractionation factors of geochemical interest, in: Data of Geochemistry, edited by: Fleischer, M., Geological Survey, 1977.

Fryer, P. and Fryer, G. J.: Origins of nonvolcanic seamounts in a forearc environment, Seamounts, Islands, and Atolls, 43, 6169, https://doi.org/10.1029/gm043p0061, American Geophysical Union, Washington D.C., 1987.

Fryer, P., Ambos, E. L., and Hussong, D. M.: Origin and emplacement of Mariana forearc seamounts, Geology, 13, 774-777, https://doi.org/10.1130/00917613(1985)13<774:oaeomf>2.0.co;2, 1985.

Fryer, P., Pearce, J. A., and Stokking, L. B. (Eds.): Initial Reports of the Ocean Drilling Program, vol. 125, Ocean Drilling Program, College Station (TX), https://doi.org/10.2973/odp.proc.ir.125.1990, 1990.

Fryer, P., Mottl, M., Johnson, L., Haggerty, J., Phipps, S., and Maekawa, H.: Serpentine bodies in the forearcs of western Pacific convergent margins: origin and associated fluids, Geoph. Monog. Ser., 88, 259-279, https://doi.org/10.1029/gm088p0259, 1995.

Fryer, P., Wheat, C. G., Williams, T., Albers, E., Bekins, B., Debret, B. P. R., Deng, J., Dong, Y., Eickenbusch, P., Frery, E. A., Ichiyama, Y., Jonson, K., Jonston, R. M., Kevorkian, R. T., Kurz, W., Magalhaes, V., Mantovanelli, S. S., Menapace, W., Menzies, C. D., Michibayashi, K., Moyer, C. L., Mullane, K. K., Park, J.-W., Price, R. E., Ryan, J. G., Shervais, J. W., Sissmann, O. J., Suzuki, S., Takai, K., Walter, B., and Zhang, R.: Expedition 366 methods, in: Proceedings of the Interna- tional Ocean Discovery Program, vol. 366, edited by: Fryer, P., Wheat, C. G., Williams, T., and the Expedition 366 Scientists, International Ocean Discovery Program, College Station (TX), https://doi.org/10.14379/iodp.proc.366.102.2018, 2018a.

Fryer, P., Wheat, C. G., Williams, T., Albers, E., Bekins, B., Debret, B. P. R., Deng, J., Dong, Y., Eickenbusch, P., Frery, E. A., Ichiyama, Y., Jonson, K., Jonston, R. M., Kevorkian, R. T., Kurz, W., Magalhaes, V., Mantovanelli, S. S., Menapace, W., Menzies, C. D., Michibayashi, K., Moyer, C. L., Mullane, K. K., Park, J.-W., Price, R. E., Ryan, J. G., Shervais, J. W., Sissmann, O. J., Suzuki, S., Takai, K., Walter, B., and Zhang, R.: Expedition 366 summary, in: Proceedings of the International Ocean Discovery Program, vol. 366, edited by: Fryer, P., Wheat, C. G., Williams, T., and the Expedition 366 Scientists, International Ocean Discovery Program, College Station (TX), https://doi.org/10.14379/iodp.proc.366.101.2018, 2018b.

Fryer, P., Wheat, C. G., Williams, T., Albers, E., Bekins, B., Debret, B. P. R., Deng, J., Dong, Y., Eickenbusch, P., Frery, E. A., Ichiyama, Y., Jonson, K., Jonston, R. M., Kevorkian, R. T., Kurz, W., Magalhaes, V., Mantovanelli, S. S., Menapace, W., Menzies, C. D., Michibayashi, K., Moyer, C. L., Mullane, K. K., Park, J.-W., Price, R. E., Ryan, J. G., Shervais, J. W., Sissmann, O. J., Suzuki, S., Takai, K., Walter, B., and Zhang, R.: Site U1492, in: Proceedings of the International Ocean Discovery Program, vol. 366, edited by: Fryer, P., Wheat, C. G., Williams, T., and the Expedition 366 Scientists, International Ocean Discovery Program, College Station (TX), https://doi.org/10.14379/iodp.proc.366.105.2018, 2018c.

Fryer, P., Wheat, C. G., Williams, T., Albers, E., Bekins, B., Debret, B. P. R., Deng, J., Dong, Y., Eickenbusch, P., Frery, E. A., Ichiyama, Y., Jonson, K., Jonston, R. M., Kevorkian, R. T., Kurz, W., Magalhaes, V., Mantovanelli, S. S., Menapace, W., Menzies, C. D., Michibayashi, K., Moyer, C. L., Mullane, K. K., Park, J.-W., Price, R. E., Ryan, J. G., Shervais, J. W., Sissmann, O. J., Suzuki, S., Takai, K., Walter, B., and Zhang, R.: Site U1496, in: Proceedings of the International Ocean Discovery Program, vol. 366, edited by: Fryer, P., Wheat, C. G., Williams, T., and the Expedition 366 Scientists, International Ocean Discovery Program, College Station (TX), https://doi.org/10.14379/iodp.proc.366.107.2018, 2018d.

Fryer, P., Wheat, C. G., Williams, T., Albers, E., Bekins, B., Debret, B. P. R., Deng, J., Dong, Y., Eickenbusch, P., Frery, E. A., Ichiyama, Y., Jonson, K., Jonston, R. M., Kevorkian, R. T., Kurz, W., Magalhaes, V., Mantovanelli, S. S., Menapace, W., Menzies, C. D., Michibayashi, K., Moyer, C. L., Mullane, K. K., Park, J.-W., Price, R. E., Ryan, J. G., Shervais, J. W., Sissmann, O. J., Suzuki, S., Takai, K., Walter, B., and Zhang, R.: Sites U1493, U1494, and U1495, in: Proceedings of the International Ocean Discovery Program, vol. 366, edited by: Fryer, P., Wheat, C. G., Williams, T., and the Expedition 366 Scientists, International Ocean Discovery Program, College Station (TX), https://doi.org/10.14379/iodp.proc.366.106.2018, 2018e.

Fryer, P., Wheat, C. G., Williams, T., Kelley, C., Johnson, K., Ryan, J., Kurz, W., Shervais, J., Albers, E., Bekins, B., Deng, J., Dong, Y., Eickenbusch, P., Frery, E., Ichiyama, Y., Johnson, R., Kevorkian, R., Magalhaes, V., Mantovanelli, S., Menapace, W., Menzies, C., Michibayashi, K., Moyer, C., Mullane, K., Park, J.-W., Price, R., Sissman, O., Suzuki, S., Takai, K., Walter, B., Zhang, R., Amon, D., Glickson, D., and Pomponi, S.: Mariana 
serpentinite mud volcanism exhumes subducted seamount materials: implications for the origin of life, Phil. Trans. Soc. A, in review, 2019.

Fryer, P. B.: A synthesis of Leg 125 drilling of serpentinite seamounts on the Mariana and Izu-Bonin forearcs, in: Proceedings of the Ocean Drilling Program, vol. 125, edited by: Fryer, P., Pearce, J. A., and Stokking, L. B., International Ocean Discovery Program, College Station (TX), 593-614, https://doi.org/10.2973/odp.proc.sr.125.168.1992, 1992.

Fryer, P. B.: Evolution of the Mariana convergent plate margin system, Rev. Geophys., 34, 89-125, https://doi.org/10.1029/95RG03476, 1996.

Fryer, P. B.: Serpentinite mud volcanism: observations, processes, and implications, Ann. Rev. Mar. Sci., 4, 345-373, https://doi.org/10.1146/annurev-marine-120710-100922, 2012.

Fryer, P. B. and Salisbury, M. H.: Leg 195 synthesis: Site 1200 - serpentinite seamounts of the Izu-Bonin Mariana convergent plate margin (ODP Leg 125 and 195 drilling results), in: Proceedings of the Ocean Drilling Program, vol. 195, edited by: Shinohara, M., Salisbury, M. H., and Richter, C., Integrated Ocean Drilling Program, College Station (TX), https://doi.org/10.2973/odp.proc.sr.195.112.2006, 2006.

Fryer, P. B., Wheat, C. G., and Mottl, M. J.: Mariana blueschist mud volcanism: implications for conditions within the subduction zone, Geology, 27(2), 103-106, https://doi.org/10.1130/00917613(1999)027<0103:mbmvif>2.3.co;2, 1999.

Füri, E., Hilton, D. R., Tryon, M. D., Brown, K. M., McMurtry, G. M., Brückmann, W., and Wheat, C. G.: Carbon release from submarine seeps at the Costa Rica fore arc: implications for the volatile cycle at the Central America convergent margin, Geochem. Geophys. Geosyst., 11, Q04S21-Q04S21, https://doi.org/10.1029/2009gc002810, 2010.

German, C. R. and Elderfield, H.: Application of the Ce anomaly as a paleoredox indicator: the ground rules, Paleoceanography, 5, 823-833, https://doi.org/10.1029/pa005i005p00823, 1990.

German, C. R., Holliday, B. P., and Elderfield, H.: Redox cycling of rare earth elements in the suboxic zone of the Black Sea, Geochim. Cosmochim. Acta, 55, 3553-3558, https://doi.org/10.1016/0016-7037(91)90055-a, 1991.

Gharib, J. J.: Clastic metabasites and authigenic minerals within serpentinite protrusions from the Mariana forearc: implications for sub-forearc subduction processes, Ph.D. thesis, University of Hawai'i, 209 pp., 2006.

Gorman, P. J., Kerrick, D. M., and Connolly, J. A. D.: Modeling open system metamorphic decarbonation of subducting slabs, Geochem. Geophys. Geosyst., 7, Q04007, https://doi.org/10.1029/2005gc001125, 2006.

Grossman, E. L. and Ku, T.-L.: Oxygen and carbon isotope fractionation in biogenic aragonite: temperature effects, Chem. Geol., 59, 59-74, https://doi.org/10.1016/0168-9622(86)90057-6, 1986.

Grozeva, N. G., Klein, F., Seewald, J. S., and Sylva, S. P.: Experimental study of carbonate formation in oceanic peridotite, Geochim. Cosmochim. Acta, 199, 264-286, https://doi.org/10.1016/j.gca.2016.10.052, 2017.

Hacker, B. R., Peacock, S. M., Abers, G. A. and Holloway, S. D.: Subduction factory 2, Are intermediatedepth earthquakes in subducting slabs linked to metamorphic dehydration reactions?, J. Geophys. Res., 108, 2030, https://doi.org/10.1029/2001jb001129, 2003.
Haggerty, J. A.: Petrology and geochemistry of Neocene sedimentary rocks from Mariana forearc seamounts: implications for emplacement of the seamounts, Geoph. Monog. Ser., 4, 175-185, https://doi.org/10.1029/gm043p0175, 1987.

Haggerty, J. A.: Evidence from fluid seeps atop serpentine seamounts in the Mariana Forearc: Clues for emplacement of the seamounts and their relationship to forearc tectonics, Mar. Geol., 102, 293-309, https://doi.org/10.1016/00253227(91)90013-t, 1991.

Harris, M., Coggon, R. M., Smith-Duque, C. E., Cooper, M. J., Milton, J. A., and Teagle, D. A. H.: Channelling of hydrothermal fluids during the accretion and evolution of the upper oceanic crust: $\mathrm{Sr}$ isotope evidence from ODP Hole 1256D, Earth Planet. Sc. Lett., 416, 56-66, https://doi.org/10.1016/j.eps1.2015.01.042, 2015 .

Helgeson, H. C., Owens, C. E., Knox, A. M., and Richard, L.: Calculation of the standard molal thermodynamic properties of crystalline, liquid, and gas organic molecules at high temperatures and pressures, Geochim. Cosmochim. Acta, 62, 985-1081, https://doi.org/10.1016/s0016-7037(97)00219-6, 1998.

Heling, D. and Schwarz, A.: Iowaite in serpentinite muds at Sites $778,779,780$, and 784: a possible cause for the low chlorinity of pore waters, in: Proceedings of the Ocean Drilling Program, vol. 125, edited by: Fryer, P., Pearce, J. A., and Stokking, L. B., International Ocean Discovery Program, College Station (TX), 313323, https://doi.org/10.2973/odp.proc.sr.125.176.1992, 1992.

Hermann, J., Spandler, C., Hack, A., and Korsakov, A. V.: Aqueous fluids and hydrous melts in high-pressure and ultra-high pressure rocks: implications for element transfers in subduction zones, Lithos, 92, 399-317, https://doi.org/10.1016/j.lithos.2006.03.055, 2006.

Hulme, S. M., Wheat, C. G., Fryer, P., and Mottl, M. J.: Pore water chemistry of the Mariana serpentinite mud volcanoes: a window to the seismogenic zone, Geochem. Geophys. Geosyst., 11, Q01X09, https://doi.org/10.1029/2009GC002674, 2010.

Jochum, K. P., Weis, U., Stoll, B., Kuzmin, D., Yang, Q., Raczek, I., Jacob, D. E., Stracke, A., Birbaum, K., Frick, D. A., Günther, D., and Enzweiler, J.: Determination of reference values for NIST SRM 610-617 glasses following ISO guidelines, Geostand. Geoanal. Res., 35, 397-429, https://doi.org/10.1111/j.1751908x.2011.00120.x, 2011.

Johannes, W. and Puhan, D., The calcite-aragonite transition, reinvestigated, Contrib. Mineral. Petrol., 31, 28-38, https://doi.org/10.1007/bf00373389, 1971.

John, T., Klemd, R., Gao, J., and Garbe-Schönberg, C.-D.: Traceelement mobilization in slabs due to non steady-state fluidrock interaction: constraints from an eclogite-facies transport vein in blueschist (Tianshan, China), Lithos, 103, 1-24, https://doi.org/10.1016/j.lithos.2007.09.005, 2008.

Johnson, J. W., Oelkers, E. H., and Helgeson, H. C.: SUPCRT92: a software package for calculating the standard molal thermodynamic properties of minerals, gases, aqueous species, and reactions from 1 to 5000 bar and 0 to $1000 \mathrm{C}$, Comput. Geosci., 18, 899-947, https://doi.org/10.1016/0098-3004(92)90029-q, 1992.

Kahl, W.-A., Jöns, N., Bach, W., Klein, F., and Alt, J. C.: Ultramafic clasts from the South Chamorro serpentine mud volcano reveal a polyphase serpentinization history of the Mariana forearc mantle, Lithos, 227, 1-20, https://doi.org/10.1016/j.lithos.2015.03.015, 2015. 
Karpoff, A. M., France-Lanord, C., Lothe, F., and Karcher, P.: Miocene tuff from Mariana basin, Leg 129, Site 802: a first deep-sea occurrence of thaumasite, in: Scientific Results, vol. 129, edited by: Larson, R. L. and Lancelot, Y., Ocean Drilling Program, College Station (TX), 119-135, https://doi.org/10.2973/odp.proc.sr.129.113.1992, 1992.

Kastner, M.: Authigenic silicates in deep-sea sediments: formation and diagensis, in: The sea, vol. 7: the oceanic lithosphere, edited by: Emiliani, C., Wiley, London, 515-980, 1981.

Kawagucci, S., Miyazaki, J., Morono, Y., Seewald, J. S., Wheat, C. G., and Takai, K.: Cool, alkaline serpentinite formation fluid regime with scarce microbial habitability and possible abiotic synthesis beneath the South Chamorro seamount, Prog. Earth Planet. Sci., 5, 74, https://doi.org/10.1186/s40645-018-0232-3, 2018.

Kelemen, P. B. and Manning, C. E.: Reevaluating carbon fluxes in subduction zones, what goes down, mostly comes up, P. Natl. Acad. Sci. USA, 112, E3997-E4006, https://doi.org/10.1073/pnas.1507889112, 2015.

Kerrick, D. M. and Connolly, J. A. D.: Subduction of ophicarbonates and recycling of $\mathrm{CO}_{2}$ and $\mathrm{H}_{2} \mathrm{O}$, Geology, 26, 375-378, https://doi.org/10.1130/00917613(1998)026<0375:sooaro>2.3.co;2, 1998.

Kerrick, D. M. and Connolly, J. A. D.: Metamorphic devolatilization of subducted marine sediments and the transport of volatiles into the Earth's mantle, Nature, 411, 293, https://doi.org/10.1038/35077056, 2001.

Klein, F., Humphris, S. E., Guo, W., Schubotz, F., Schwarzenbach, E. M., and Orsi, W. D.: Fluid mixing and the deep biosphere of a fossil Lost City-type hydrothermal system at the Iberia Margin, P. Natl. Acad. Sci. USA, 112, 12036-12041, https://doi.org/10.1073/pnas.1504674112, 2015.

Lafuente, B., Downs, R. T., Yang, H., and Stone, N.: The power of databases: the RRUFF project, in: Highlights in mineralogical crystallography, de Gruyter, 1-29, https://doi.org/10.1515/9783110417104-003, 2016.

Leterrier, J., Maury, R. C., Thonon, P., Girard, D., and Marchal, M.: Clinopyroxene composition as a method of identification of the magmatic affinities of paleo-volcanic series, Earth Planet. Sc. Lett., 59, 139-154, https://doi.org/10.1016/0012821x(82)90122-4, 1982.

Maekawa, H., Masaya, S., Ishill, T., Fryer, P., and Pearce, J. A.: Blueschist metamorphism in an active subduction zone, Nature, 364, 520-523, https://doi.org/10.1038/364520a0, 1993.

Maekawa, H., Fryer, P. B., and Ozaki, A.: Incipient blueschist-facies metamorphism in the active subduction zone beneath the Mariana forearc, in: Active margins and marginal basins of the western Pacific, vol. 88, edited by: Taylor, B. and Natland, J., 281289, https://doi.org/10.1029/gm088p0281, 1995.

McCollom, T. M. and Bach, W.: Thermodynamic constraints on hydrogen generation during serpentinization of ultramafic rocks, Geochim. Cosmochim. Acta, 73, 856-875, https://doi.org/10.1016/j.gca.2008.10.032, 2009.

McDonough, W. F. and Sun, S.-S.: The composition of the Earth, Chem. Geol., 120, 223-253, https://doi.org/10.1016/00092541(94)00140-4, 1995.

Molina, J. F. and Poli, S.: Carbonate stability and fluid composition in subducted oceanic crust: an experimental study on
$\mathrm{H}_{2} \mathrm{O}-\mathrm{CO}_{2}$-bearing basalts, Earth Planet. Sc. Lett., 176, 295-310, https://doi.org/10.1016/s0012-821x(00)00021-2, 2000.

Mottl, M. J., Komor, S. C., Fryer, P., and Moyer, C. L.: Deep-slab fluids fuel extremophilic Archaea on a Mariana forearc serpentinite mud volcano: Ocean Drilling Program Leg 195, Geochem. Geophys. Geosyst., 4, 9009, https://doi.org/10.1029/2003GC000588, 2003.

Mottl, M. J., Wheat, C. G., Fryer, P. B., Gharib, J., and Martin, J. B.: Chemistry of springs across the Mariana forearc shows progressive devolatilization of the subducting plate, Geochim. Cosmochim. Acta, 68, 4915-4933, https://doi.org/10.1016/j.gca.2004.05.037, 2004.

Müller, R. D., Sdrolias, M., Gaina, C., and Roest, W. R.: Age, spreading rates, and spreading asymmetry of the world's ocean crust, Geochem. Geophys. Geosyst., 9, Q04006, https://doi.org/10.1029/2007GC001743, 2008.

Newton, R. C. and Manning, C. E.: Experimental determination of calcite solubility in $\mathrm{H} 2 \mathrm{O}-\mathrm{NaCl}$ solutions at deep crust/upper mantle pressures and temperatures: Implications for metasomatic processes in shear zones, Am. Miner., 87, 1401-1409, https://doi.org/10.2138/am-2002-1016, 2002.

Noack, Y:: Occurrence of thaumasite in a seawaterbasalt interaction, Mururoa atoll (French Polynesia, South Pacific), Miner. Mag., 47, 47-50, https://doi.org/10.1180/minmag.1983.047.342.08, 1983.

Oakley, A. J., Taylor, B., Fryer, P. B., Moore, G. F., Goodliffe, A. M., and Morgan, J. K.: Emplacement, growth, and gravitational deformation of serpentinite seamounts on the Mariana forearc, Geophys. J. Int., 170, 615-634, https://doi.org/10.1111/j.1365246X.2007.03451.x, 2007.

Oakley, A. J., Taylor, B., and Moore, G. F.: Pacific plate subduction beneath the central Mariana and Izu-Bonin fore arcs: new insights from an old margin, Geochem. Geophys. Geosyst., 9, Q06003, https://doi.org/10.1029/2007GC001820, 2008.

O’Neil, J. R., Clayton, R. N., and Mayeda, T. K.: Oxygen isotope fractionation in divalent metal carbonates, J. Chem. Phys., 51, 5547-5558, https://doi.org/10.1063/1.1671982, 1969.

Pälike, H., Lyle, M. W., Nishi, H., Raffi, I., Ridgwell, A., Gamage, K., Klaus, A., Acton, G., Anderson, L., Backman, J., Baldauf, J., Beltran, C., Bohaty, S. M., Bown, P., Busch, W., Channell, J. E. T., Chun, O. J., Delaney, M., Dewangan, P., Jones, T. D., Edgar, K. M., Evans, H., Fitch, P., Foser, G. L., Gussone, N., Hasegawa, H., Hathorne, E. D., Hayashi, H., Herrle, J. O., Holbourn, A., Hovan, S., Hyeong, K., Iijima, K., Ito, T., Kamikuri, S., Kimoto, K., Kuroda, J., Leon-Rodriguez, L., Malinverno, A., Moore Jr., T. C., Murphy, B. H., Murphy, D. P., Nakamura, H., Ogane, K., Ohneiser, C., Richter, C., Robinson, R., Rohling, E. J., Romero, O., Sawada, K., Scher, H., Schneider, L., Sluijs, A., Takata, H., Tian, J., Tsujimoto, A., Wade, B. S., Westerhold, T., Wilkens, R., Williams, T., Wilson, P. A., Yamamoto, Y., Yamamoto, S., Yamazaki, T., and Zeebe, R. E.: A Cenozoic record of the equatorial Pacific carbonate compensation depth, Nature, 488, 609-614, https://doi.org/10.1038/nature11360, 2012.

Paytan, A., Kastner, M., Campbell, D., and Thiemens, M. H.: Seawater sulfur isotope fluctuations in the Cretaceous, Science, 304, 1663-1665, https://doi.org/10.1126/science.1095258, 2004.

Phipps, S. P. and Ballotti, D.: Rheology of serpentinite muds in the Mariana-Izu-Bonin forearc, in: Proceedings of the Ocean Drilling Program, vol. 125, edited by: Fryer, 
P. B., Pearce, J. A., and Stokking, L. B., International Ocean Discovery Program, College Station (TX), 363-372, https://doi.org/10.2973/odp.proc.sr.125.154.1992, 1992.

Piccoli, F., Brovarone, A. V, Beyssac, O., Martinez, I., Ague, J. J., and Chaduteau, C.: Carbonation by fluid-rock interactions at high-pressure conditions: implications for carbon cycling in subduction zones, Earth Planet. Sc. Lett., 445, 146-159, https://doi.org/10.1016/j.epsl.2016.03.045, 2016.

Piepgras, D. J. and Jacobsen, S. T.: The behavior of rare earth elements in seawater: precise determination of variations in the North Pacific water column, Geochim. Cosmochim. Acta, 56, 1851-1862, https://doi.org/10.1016/0016-7037(92)90315-a, 1992.

Plank, T. and Langmuir, C. H.: The chemical composition of subducting sediment and its consequences for the crust and mantle, Chem. Geol., 145, 325-394, https://doi.org/10.1016/s00092541(97)00150-2, 1998.

Poli, S., Franzolin, E., Fumagalli, P., and Crottini, A.: The transport of carbon and hydrogen in subducted oceanic crust: an experimental study to $5 \mathrm{GPa}$, Earth Planet. Sc. Lett., 278, 350-360, https://doi.org/10.1016/j.epsl.2008.12.022, 2009.

Pons, M.-L., Quitté, G., Fujii, T., Rosing, M. T., Reynard, B., Moynier, C. D., and Albarède, F.: Early Archean serpentine mud volcanoes at Isua, Greenland, as a niche for early life, P. Natl. Acad. Sci. USA, 108, 17639-17643, https://doi.org/10.1073/pnas.1108061108, 2011.

Rausch, S.: Carbonate veins as recorders of seawater evolution, $\mathrm{CO}_{2}$ uptake by the ocean crust, and seawater-crust interaction during low-temperature alteration, Ph.D. thesis, Department of Geosciences, University of Bremen, 156 pp., 2012.

Robie, R. A. and Hemingway, B. S.: Thermodynamic properties of minerals and related substances at $298.15 \mathrm{~K}$ and 1 bar $\left(10^{5}\right.$ pascals) pressure and at higher temperatures, USGS Bull., 2131, https://doi.org/10.3133/b2131, US Geological Survey, Washington D.C., 456 pp., 1995.

Robie, R. A., Hemingway, B. S., and Fisher, J. R.: Thermodynamic properties of minerals and related substances at $298.15 \mathrm{~K}$ and 1 bar ( $\left(10^{5}\right.$ pascals $)$ pressure and at higher temperatures, USGS Bull., 1452, https://doi.org/10.3133/b1452, US Geological Survey, Washington D.C., 461 pp., 1978.

Schmidt, T., Lothenbach, B., Romer, M., Scrivener, K., Rentsch, D., and Figi, R.: A thermodynamic and experimental study of the conditions of thaumasite formation, Cem. Concr. Res., 38, 337349, https://doi.org/10.1016/j.cemconres.2007.11.003, 2008.

Schroeder, T., Bach, W., Jöns, N., Jöns, S., Monien, P., and Klügel, A.: Fluid circulation and carbonate vein precipitation in the footwall of an oceanic core complex, Ocean Drilling Program Site 1275, Mid-Atlantic Ridge, Geochem. Geophys. Geosyst., 16, 3716-3732, https://doi.org/10.1002/2015gc006041, 2015.

Schwarzenbach, E. M., Caddick, M. J., Petroff, M., Gill, B. C., Cooperdock, E. H. G., and Barnes, J. D.: Sulphur and carbon cycling in the subduction zone mélange, Sci. Rep., 8, 15517, https://doi.org/10.1038/s41598-018-33610-9, 2018.

Shipboard Scientific Party: Site 780, in: Proceedings of the Ocean Drilling Program, Init. Rep., vol. 125, edited by: Fryer, P., Pearce, J. A., and Stokking, L. B., Ocean Drilling Program, College Station (TX), 147-178, https://doi.org/10.2973/odp.proc.ir.125.108.1990, 1990.
Shipboard Scientific Party: Leg 185 summary: inputs to the Izu-Mariana subduction system, in: Proceedings of the Ocean Drilling Program, Init. Rep., vol. 185, edited by: Plank, T., Ludden, J. N., and Escutia, C., Ocean Drilling Program, College Station (TX), 1-63, https://doi.org/10.2973/odp.proc.ir.185.101.2000, 2000.

Shipboard Scientific Party: Explanatory notes, in: Proceedings of the Ocean Drilling Program, Init. Rep., vol. 209, edited by: Kelemen, P. B., Kikawa, E., and Miller, D. J., Ocean Drilling Program, College Station (TX), https://doi.org/10.2973/odp.proc.ir.209.102.2004, 2004.

Shock, E. L. and Helgeson, H. C.: Calculation of the thermodynamic and transport properties of aqueous species at high pressures and temperatures: correlation algorithms for ionic species and equation of state predictions to $5 \mathrm{~kb}$ and $1000 \mathrm{C}$, Geochim. Cosmochim. Acta, 52, 2009-2036, https://doi.org/10.1016/00167037(88)90181-0, 1988.

Shock, E. L., Sassani, D. C., Willis, M., and Sverjensky, D. A.: Inorganic species in geologic fluids: correlations among standard molal thermodynamic properties of aqueous ions and hydroxide complexes, Geochim. Cosmochim. Acta, 61, 907-950, https://doi.org/10.1016/s0016-7037(96)00339-0, 1997.

Sieber, M. J., Hermann, J., and Yaxley, G. M.: An experimental investigation of $\mathrm{C}-\mathrm{O}-\mathrm{H}$ fluid-driven carbonation of serpentinites under forearc conditions, Earth Planet. Sc. Lett., 496, 178-188, https://doi.org/10.1016/j.epsl.2018.05.027, 2018.

Sleep, N. H. and Zahnle, K.: Carbon dioxide cycling and implications for climate on ancient Earth, J. Geophys. Res., 106, 13731399, https://doi.org/10.1029/2000je001247, 2001.

Spandler, C., Hermann, J., Arculus, R., and Mavrogenes, J.: Redistribution of trace elements during prograde metamorphism from lawsonite blueschist to eclogite facies; implications for deep subduction-zone processes, Contrib. Mineral. Petrol., 146, 205222, https://doi.org/10.1007/s00410-003-0495-5, 2003.

Stipp, M. and Kunze, K.: Dynamic recrystallization near the brittle-plastic transition in naturally and experimentally deformed quartz aggregates, Tectonophysics, 448, 77-97, https://doi.org/10.1016/j.tecto.2007.11.041, 2008.

Suzuki, J. and Ito, M.: Nesquehonite from Yoshikawa, Aichi Prefecture, Japan: Occurrence and thermal behaviour, J. Jap. Ass. Min. Petr. Econ. Geol., 69, 275-284, https://doi.org/10.2465/ganko1941.69.275, 1974.

Sverjensky, D. A., Stagno, V., and Huang, F.: Important role for organic carbon in subduction-zone fluids in the deep carbon cycle, Nat. Geosci., 7, 909, https://doi.org/10.1038/ngeo2291, 2014.

Taetz, S., John, T., Bröcker, M., Spandler, C., and Stracke, A.: Fast intraslab fluid-flow events linked to pulses of high pore fluid pressure at the subducted plate interface, Earth Planet. Sc. Lett., 482, 33-43, https://doi.org/10.1016/j.epsl.2017.10.044, 2018.

Tostevin, R., Shields, G. A., Tarbuck, G. M., He, T., Clarkson, M. O., and Wood, R. A.: Effective use of cerium anomalies as a redox proxy in carbonate-dominated marine settings, Chem. Geol., 438, 146-162, https://doi.org/10.1016/j.chemgeo.2016.06.027, 2016.

Tran, T. H., Kato, K., Wada, H., Fujioka, K., and Matsuzaki, H.: Processes involved in calcite and aragonite precipitation during carbonate chimney formation on Conical Seamount, Mariana Forearc: evidence from geochemistry and carbon, oxy- 
gen and strontium isotopes, J. Geochem. Explor., 137, 55-64, https://doi.org/10.1016/j.gexplo.2013.11.013, 2014.

Uyeda, S. and Kanamori, H.: Back-arc opening and the mode of subduction, J. Geophys. Res., 84, 1049, https://doi.org/10.1029/jb084ib03p01049, 1979.

van Keken, P. E., Kiefer, B., and Peacock, S. M.: Highresolution models of subduction zones: implications for mineral dehydration reactions and the transport of water into the deep mantle, Geochem. Geophys. Geosyst., 3, 1056, https://doi.org/10.1029/2001gc000256, 2002.

Wheat, C. G., Fournier, T., Paul, C., Menzies, C. D., Price, R. E., Ryan, J. G., and Sissman, O. J.: Data report: IODP Expedition 366 pore water trace element (V, Mo, Rb, Cs, U, $\mathrm{Ba}$, and $\mathrm{Li}$ ) compositions, in: Proceedings of the International Ocean Discovery Program, edited by: Fryer, P., Wheat, C. G., Williams, T. and the Expedition 366 Scientists, vol. 366, 1-8, International Ocean Discovery Program, College Station (TX), https://doi.org/10.14379/iodp.proc.366.201.2018, 2018.
White, W. M. and Klein, E. M.: Composition of the oceanic crust, in: Treatise on geochemistry, edited by: Holland, $\mathrm{H}$. and Turekian, K., 457-496, https://doi.org/10.1016/b978-0-08095975-7.00315-6, Elsevier Ltd., Amsterdam, 2014.

Wilson, S. A., Dipple, G. M., Power, I. M., Thom, J. M., Anderson, R. G., Raudsepp, M., Gabites, J. E., and Southam, G.: Carbon dioxide fixation within mine wates of ultramafichosted ore deposits: examples from the Clinton Creek and Cassiar Chrysotile deposits, Canada, Econ. Geol., 104, 95-112, https://doi.org/10.2113/gsecongeo.104.1.95, 2009.

Zheng, Y.-F.: Calculation of oxygen isotope fractionation in anhydrous silicate minerals, Geochim. Cosmochim. Acta, 57, 10791091, https://doi.org/10.1016/0016-7037(93)90042-u, 1993a.

Zheng, Y.-F.: Calculation of oxygen isotope fractionation in hydroxyl-bearing silicates, Earth Planet. Sc. Lett., 120, 247-263, https://doi.org/10.1016/0012-821x(93)90243-3, 1993 b.

Zheng, Y.-F.: Oxygen isotope fractionation in carbonate and sulfate minerals., Geochem. J., 33, 109-126, https://doi.org/10.2343/geochemj.33.109, 1999. 